\title{
Molecular cloning and functional characterization of a type-I neurotensin receptor (NTR) and a novel NTR from the bullfrog brain
}

\author{
J H Li, F Sicard'1, M A Salam, M Baek, J LePrince ${ }^{1}$, H Vaudry ${ }^{1}, \mathrm{~K} \mathrm{Kim}^{2}$, H B Kwon and \\ J Y Seong ${ }^{3}$ \\ Hormone Research Center, School of Biological Sciences and Technology, Chonnam National University, Gwangju 500-757, Republic of Korea \\ ${ }^{1}$ Laboratory of Cellular and Molecular Neuroendocrinology, European Institute for Peptide Research, INSERM U413, UA CNRS, University of Rouen, 76821 Mont-Saint-Aignan, \\ France \\ ${ }^{2}$ School of Biological Sciences, Seoul National University, Seoul 151-742, Korea \\ ${ }^{3}$ Graduate School of Medicine, Korea University, Seoul 136-705, Korea
}

(Requests for offprints should be addressed to J Y Seong; Email: jyseong @korea.ac.kr)

\begin{abstract}
Neurotensin (NT) is a tridecapeptide that functions as a neurotransmitter and neuromodulator in the nervous system. To date, three different types of NT receptor (NTR), NTR1, NTR2 and NTR3, have been identified only in mammalian species. In the present study we isolated the cDNAs for an NTR1 and a novel NTR in the bullfrog brain, designated bfNTR1 and bfNTR4 respectively. bfNTR1 and bfNTR4 encode 422- and 399-amino acid residue proteins respectively. bfNTR1 has a $64 \%$ amino acid identity with mammalian NTR1, and 34-37\% identity with mammalian NTR2. bfNTR4 exhibits $43 \%$ and $45-47 \%$ identity with mammalian NTR1 and NTR2 respectively. Both receptors are mainly expressed in the brain and pituitary. bfNTR1 triggers both CRE-luc, a protein kinase A (PKA)-specific reporter, and c-fos-luc, a PKC-specific reporter, activities, indicating that bfNTR1 can activate PKA- and PKC-linked signaling pathways. However, bfNTR4 appears to be preferentially coupled to the PKA-linked pathway as it induces a higher CRE-luc activity than c-fos-luc activity. bfNTRs exhibit different pharmacological properties as compared with mammalian NTRs. Mammalian NTR1 but not NTR2 responds to NT, whereas both bfNTR1 and bfNTR4 show a high sensitivity to NT. SR 48692 and SR 142948A, antagonists for mammalian NTR1 but agonists for mammalian NTR2, function as antagonists for both bfNTR1 and bfNTR4. In conclusion, this report provides the first molecular, pharmacological and functional characterization of two NTRs in a non-mammalian vertebrate. These data should help to elucidate the phylogenetic history of the G protein-coupled NTRs in the vertebrate lineage as well as the structural features that determine their pharmacological properties.
\end{abstract}

Journal of Molecular Endocrinology (2005) 34, 793-807

\section{Introduction}

Neurotensin (NT) is a brain and gastrointestinal tridecapeptide that was originally isolated from the bovine hypothalamus (Carraway \& Leeman 1973) and subsequently from bovine intestine (Kitabgi et al. 1976). NT exhibits a dual function as a neurotransmitter or neuromodulator in the central nervous system and as a local hormone at the periphery. Central administration of NT induces various effects including modulation of dopaminergic transmission, naloxone-independent analgesia, inhibition of food intake and modulation of pituitary hormone release (Rostène \& Alexander 1997, Kitabgi 2002). There is also increasing evidence that NT plays a role in neuropsychiatric diseases, notably in schizophrenia and Parkinson's disease (McMahon et al. 2002). At the periphery, NT induces hypotension, decrease in gastric acid secretion, lipid digestion, proinflammatory response and proliferation of gut and cancer cells (Kitabgi 2002, Somai et al. 2002).

NT exerts its action through its own membrane receptors. To date, three distinct types of NT receptor, termed NTR1 (Tanaka et al. 1990, Vita et al. 1993), NTR2 (Chalon et al. 1996, Mazella et al. 1996) and NTR3 (Vita et al. 1998), have been identified in mammals. NTR1 and NTR2 have seven transmembrane helices (TMHs), a typical structure of $\mathrm{G}$ protein-coupled receptors (GPCRs), while NTR3 possesses a single transmembrane domain and belongs to a Vps10p domain receptor family (Mazella et al. 1998). Compared with NTR1, NTR2 has a relatively short extracellular N-terminal region and a long third intracellular loop (ICL3) (Vincent et al. 1999). Moreover, in NTR2, Asp at position 2.50 in TMH2 and Asn at position $7 \cdot 49$ in TMH7, the most conserved residues 
among rhodopsin-like GPCRs, are replaced by Ala/Gly and Thr respectively (Vincent et al. 1999). NTR1 exhibits a high affinity for NT but is insensitive to levocabastine, a non-peptide $\mathrm{H} 1$ histamine antagonist (Tanaka et al. 1990, Vita et al. 1993), while NTR2 has a very low affinity for NT and is sensitive to levocabastine (Chalon et al. 1996, Mazella et al. 1996). The non-peptide NTR antagonist SR 48692 has a higher affinity to NTR1 than to NTR2 (Gully et al. 1993). A second-generation antagonist, SR 142948A, exhibits a similar binding affinity to mammalian NTR1 and NTR2 (Gully et al. 1997, Betancur et al. 1998). However, it is known that SR 48692 and SR 142948A act as agonists for NTR2 when expressed in Xenopus oocytes (Botto et al. 1997, Mazella et al. 1998). Recently, $\beta$-lactotensin has been suggested as a specific agonist for NTR2 (Yamauchi et al. 2003). However, the functional relevance of NT as a ligand of NTR2 is still controversial. NT acts as an agonist for mouse NTR2 (mNTR2) when expressed in Xenopus oocyte (Mazella et al. 1996) and rat cerebellar granule cells (Sarret et al. 2002), while NT is unable to activate any second messenger systems from mNTR2 expressed in human embryonic kidney 293 (HEK293) cells, although radiolabeled NT can bind mNTR2 (Botto et al. 1998). Further, it has been suggested that NT acts as a natural antagonist for human NTR2 (hNTR2) when expressed in COS7 and CHO cells (Vita et al. 1998, Richard et al. 2001).

The signal transduction pathways associated with NTRs have been studied in various cell lines. Activation of rat NTR1 (rNTR1) induces an increase in inositol trisphosphate $\left(\mathrm{IP}_{3}\right)$ and $\mathrm{Ca}^{2+}$ mobilization through an activation of $\mathrm{G}_{\mathrm{q} / 11}$ (Watson et al. 1992, Chabry et al. 1994, Hermans et al. 1994). It has also been reported that stimulation of NTRl evokes the production of arachidonic acid and cAMP through $\mathrm{G}_{\mathrm{i} / \mathrm{o}}$ and $\mathrm{G}_{\mathrm{s}}$ activation respectively (Yamada et al. 1993, Carraway \& Mitra 1998, Gailly et al. 2000). Furthermore, levocabastine and SR 48692 trigger $\mathrm{Ca}^{2+}$ mobilization, IP production, arachidonic acid release and mitogenactivated protein kinase activity in CHO cells expressing rNTR2 or hNTR2 (Vita et al. 1998, Yamada et al. 1998).

Although the three types of NTRs have now been cloned, the physiological roles of these NTRs are still poorly understood. Using an NTR1-knockout mice model, it has been found that NTR1 is involved in the control of food consumption and body weight, but not in NT-induced analgesia (Remaury et al. 2002). On the other hand, NTR2 seems to account for the SR 48692-insensitive analgesic effect (Dubuc et al. 1999, Maeno et al. 2004). Recent studies have shown that NTR3 may control proliferation of human cancer cells (Dal Farra et al. 2001), migration of human microglia (Martin et al. 2003) and proNGF-induced neuronal cell death (Nykjaer et al. 2004).
In non-mammalian species, the primary structure of NT has been characterized in chicken (Carraway \& Bhatnagar 1980), alligator (Bello et al. 1993), python (Conlon et al. 1997) and two species of frog (Shaw et al. 1992, Desrues et al. 1998). It has also been reported that frog NT (fNT) stimulates the secretion of corticosteroids from perifused frog adrenal slices (Sicard et al. 2000) and the release of $\alpha$-melanocyte-stimulating hormone from perifused frog pars intermedia cells (Desrues et al. 1998). The latter process appears to be mediated by a receptor which shares pharmacological characteristics with both mammalian NTR1 and NTR2 (Belmeguenai et al. 2000). However, to date, NTRs have not been characterized in any non-mammalian vertebrate species. In the present study using the bullfrog, we have cloned and characterized an NTR 1 like receptor (bfNTR 1 ) and a novel NTR (bfNTR4) that is structurally and functionally different from mammalian NTR2.

\section{Materials and methods}

\section{Materials}

Oligonucleotides were purchased from GenoTech Co. (Seoul, Korea). The pcDNA3 expression vector was purchased from Invitrogen. All constructs of mammalian NTRs were a generous gift from Dr J Mazella (CNRS, Valbonne, France). The pCMV $\beta$-gal was purchased from Clontech. The CRE-luc vector that contains four copies of the cAMP response element (CRE, TGACGTCA) was obtained from Stratagene (La Jolla, CA, USA). The c-fos-luc vector containing the $-711 \sim+45$ sequence of the human c-fos promoter constructed in the pFLASH vector, was a kind gift from Dr R Prywes (Columbia University, NY, USA). Taq DNA polymerase was purchased from Promega. Vent polymerase was obtained from New England Biotech (Beverly, MA, USA). Frog (Rana ridibunda) NT (Table 2) was synthesized by the solid phase methodology on an Applied Biosystem model 432 synthesizer (St Quentin en Yvelines, France), using an Fmoc-Leu-PEG-PS resin, by the standard Fmoc procedure as previously described (Desrues et al. 1998). hNT, porcine NMN $(\mathrm{pNMN})$ and NT(8-13) were obtained from Sigma. The NT analogs JMV 431, JMV 457, JMV 458 and JMV 510 (Table 2) were kindly provided by Dr Jean Martinez (CNRS UMR 5810, University of Montpellier 2, France). Levocabastine was a generous gift from Janssen Pharmaceutica (Beerse, Belgium). SR 48692 and SR 142948A (Table 2) were generously given by Sanofi-Synthelabo (Montpellier, France).

\section{Animals and tissue preparation}

Adult bullfrogs were purchased from a local supplier (BCPC, Taein, Korea) and housed in flow-through tanks 
Table 1 Primers used for cloning bullfrog NTRs

\begin{tabular}{|c|c|c|}
\hline & Primers & Sequences \\
\hline \multicolumn{3}{|l|}{ Application } \\
\hline \multirow{2}{*}{ NTR1 partial } & NTR-F4 & $5^{\prime}-\mathrm{CA}[\mathrm{C} / \mathrm{T}][\mathrm{C} / \mathrm{T}] \mathrm{A}[\mathrm{C} / \mathrm{T}] \mathrm{CCCTGGG[C/T]CTT[T/C]GG[G/C]GA}$ \\
\hline & NTR-R1 & $5^{\prime}-\mathrm{C}[\mathrm{A} / \mathrm{G}] \mathrm{TG}[\mathrm{G} / \mathrm{A}] \mathrm{TA}[\mathrm{G} / \mathrm{C}] \mathrm{GGCA}[\mathrm{G} / \mathrm{A}] \mathrm{CCA}[\mathrm{G} / \mathrm{A}] \mathrm{CAGA}$ \\
\hline \multirow[t]{2}{*}{ NTR4 partial } & dNTR4-F1 & $5^{\prime}-\mathrm{GA}[\mathrm{A} / \mathrm{G}][\mathrm{C} / \mathrm{T}] \mathrm{TGTG}[\mathrm{C} / \mathrm{T}] \mathrm{GCNTA}[\mathrm{C} / \mathrm{T}] \mathrm{GCNAC}$ \\
\hline & NTR-R3 & 5'-GCGGTGGTCA[C/G]CATGTAGAA[G/A]TAGTG \\
\hline \multirow{2}{*}{ NTR4 partial (nest PCR) } & dNTR4-F2 & 5'-CCNATGGCNGT/C/T]AT[A/T/C]ATGGG \\
\hline & NTR-R2 & $5^{\prime}-\mathrm{GGG}[\mathrm{T} / \mathrm{G}] \mathrm{A}[\mathrm{C} / \mathrm{T}][\mathrm{A} / \mathrm{G}] \mathrm{TAGCAG[T/A]ACATGAG}$ \\
\hline \multirow{2}{*}{ NTR1 5'RACE } & bfNT1-5'GSP1 & 5'-TTGAAGGTGGACATCTCCAGAGTCCTCGTG \\
\hline & bfNT1-5'GSP2 & 5'-TGCAGACCAGGTGATCTGGGTCTTCCA \\
\hline \multirow{3}{*}{ NTR1 3'RACE } & bfNT1-3'GSP1 & 5'-TGCCAGCCTCAGCATGGAGAGGTACATG \\
\hline & bfNT1-3'GSP2 & 5'-AGGCCAAAAGCATCATGTCAAGGAGCAGGAC \\
\hline & bfNT1-3'GSP3 & 5'-CCGATGATTGCAATCTCCGTTCTCAACACC \\
\hline \multirow[t]{3}{*}{ NTR4 5'RACE } & bfNT4 5'GSP1 & 5'-GCTGTGTTGCAGTGACTGTATACGGTGGG \\
\hline & bfNT4 5'GSP2 & 5'-GCTGTGTTGCAGTGACTGTATACGGTGGG \\
\hline & bfNT4 5'GSP3 & 5'-CCGGCTCTCCATCTGGGCTCATGTTCTC \\
\hline \multirow[t]{2}{*}{ NTR4 3'RACE } & bfNT4 3'GSP1 & 5'-CAAGTATGAGAACATGAGCCCAGATGGAGAGC \\
\hline & bfNT4 3'GSP2 & 5'-CCGGATCCCTCATCACTTATCTGCACTAGTC \\
\hline \multirow[t]{2}{*}{ NTR1 ORF } & bfNTR1-F & 5'-CGGAATTCACCACCATGAACCCCGGCTCTGCAGCTGAA \\
\hline & bfNTR1-R & 5'-GCTCTAGATCAGTATGGAGTTTCCCTGGTGAT \\
\hline \multirow[t]{2}{*}{ NTR4 ORF } & bfNTR4-F & $5^{\prime}$-CCCAAGCTTACCACCATGCTGGCACTACAGAATTCCACC \\
\hline & bfNTR4-R & 5'-GCTCTAGACATCAGTCCGGTCTGATGTGC \\
\hline
\end{tabular}

Restriction enzyme sites are underlined and Kozak and stop codons are in bold.

under simulated natural conditions. Frogs were killed by decapitation. The tissues of interest were quickly dissected and immediately frozen in liquid nitrogen, and stored at $-80^{\circ} \mathrm{C}$ until use. Animal experiments were conducted in accordance with the Guidelines for the Care and Use of Experimental Animals at Chonnam National University.

\section{RNA isolation}

Total RNA was extracted from frozen tissues by Tri reagent (MRC, Inc., Cincinnati, OH, USA) according to the manufacturer's instructions. RNA quality was examined by electrophoresis on $1 \%$ formaldehyde agarose gels. The RNA, which showed two sharp bands of $18 \mathrm{~S}$ and $28 \mathrm{~S}$, was stored at $-80^{\circ} \mathrm{C}$ until use. Poly $(\mathrm{A})^{+}$RNA was prepared by using an RNeasy mini kit (Qiagen).

\section{Isolation of partial fragments for bfNTR1 and bfNTR4}

One microgram of total RNA isolated from the brain was reverse transcribed at $42{ }^{\circ} \mathrm{C}$ for $1 \mathrm{~h}$ followed by an incubation at $52{ }^{\circ} \mathrm{C}$ for $30 \mathrm{~min}$ in $20 \mu \mathrm{l}$ of reaction buffer containing $1 \mathrm{mM}$ of each dNTP, $200 \mathrm{U}$ of AMV reverse transcriptase (Promega), $20 \mathrm{U}$ of RNAgard Rnase Inhibitor (Amersham Pharmacia Biotech) and $0.5 \mu \mathrm{g}$ oligo-deoxythymidine primer. Synthesized cDNA was amplified with the primer sets NTR-F4 and NTR-R1 (for bfNTR1) or dNTR4-F1 and NTR-R3 (for bfNTR4) (Table 1) under 35 cycles of denaturation at $94{ }^{\circ} \mathrm{C}$ for
$30 \mathrm{~s}$, annealing at $50{ }^{\circ} \mathrm{C}$ for $50 \mathrm{~s}$ and extension at $72{ }^{\circ} \mathrm{C}$ for $1 \mathrm{~min}$. For bfNTR4, a nest PCR was performed with primers dNTR4-F and NTR-R2 in the same PGR condition. PGR products were cloned into the pGEM-T easy vector (Promega). Positive clones were sequenced by a sequenase version 2.0 DNA sequencing kit (USB Corporation, Cleveland, OH, USA).

\section{5'- and 3'-rapid amplification of CDNA ends (RACE)}

A cDNA library was constructed from brain Poly $(\mathrm{A})^{+}$ RNA using a Marathon cDNA amplification kit (Clontech) according to the manufacturer's instruction. 5 '-RACE was performed by using adapter primer 1 (Apl) combined with the gene-specific primers bfNT1-5'GSP1 (bfNTR1) or bfNT4-5'GSP1 (bfNTR4) (Table 1). The PCR products were diluted and further amplified with adapter primer 2 (Ap2) combined with the gene-specific primers bfNT1-5'GSP2 (bfNTR1) or bfNT4-5'GSP3 (bfNTR4) (Table 1). 3'-RACE was performed by using Apl combined with the genespecific primers bfNT1-3'GSPl (bfNTRl) or bfNT43'GSP1 (bfNTR4) (Table 1). The PCR products were diluted and further amplified with Ap2 combined with the gene-specific primers bfNT1-3'GSP3 (bfNTR1) or bfNT4-3'GSP2 (bfNTR4) (Table 1). RACE products were cloned into the pGEM-T easy vector and transformed into DH5 $\alpha$ competent cells. White colonies containing the right sized PCR product were sequenced by using an automatic ABI prism 377 DNA sequencer (Perkin-Elmer, Wellesley, MA, USA). 
Table 2 NTR ligands used in this study

\section{Amino acid sequence or chemical formula}

\author{
Compounds \\ Frog NT \\ Human NT \\ Porcine NMN \\ NT(8-13) \\ Boc-[Trp $\left.\left.{ }^{11}\right] \mathrm{NT}^{\star} 8-13\right)(\mathrm{JMV} 458)$ \\ Boc-[D-Trp $\left.{ }^{11}\right] N T(8-13)$ (JMV 457) \\ Boc- $\left[\mathrm{Lys}^{8,9}, \mathrm{Nal}^{11}\right] \mathrm{NT}(8-13)(\mathrm{JMV} 510)$ \\ Boc-[psi $\left.{ }^{11,12}\right] \mathrm{NT}(8-13)$ (JMV 431) \\ SR 48692
}

SR $14948 A$

\author{
pGlu Ala His Ile Ser Lys Ala Arg Arg Pro Tyr Ile Leu \\ pGlu Leu Tyr Glu Asn Lys Pro Arg Arg Pro Tyr Ile Leu \\ Lys Ile Pro Tyr lle Leu \\ Arg Arg Pro Tyr lle Leu \\ Boc Arg Arg Pro Trp lle Leu \\ Boc Arg Arg Pro D-Trp lle Leu \\ Boc Lys Lys Pro Nal lle Leu \\ Boc Arg Arg Pro Tyr psi $\left(\mathrm{CH}_{2} \mathrm{NH}\right)$ lle Leu \\ 2-[(1-(7-chloro-4-quinolinyl]-5-[2,6-dimethoxyphenyl]pyiazol-3-yl]carbonylamina]ticyclo- \\ (3.3.1.1)decan-2-carboxylic acid) \\ 2-[(5-[2,6-dimethoxyphenyl]-1-[4-(N-[3-dimethylamina propyl]-N-methylcarbamoyl)2- \\ isopropylphenyl]-1H-pyrazole-3-carbonyl)amino]adamantane- \\ 2-carboxylic acid hydrochloride
}

\section{Cloning of the full-length open-reading frame (ORF) of bfNTRs}

The ORFs of bfNTR 1 and bfNTR 4 were amplified with Vent DNA Taq polymerase using primer sets bfNTR1-F (including EcoRI and Kozak site) and bfNTR1-R (including XbaI) or bfNTR4-F (including HindIII and Kozak site) and bfNTR4-R (including XbaI) (Table 1). The PCR products of anticipated size were digested with the corresponding restriction enzymes and ligated into pcDNA3. The selected colonies were analyzed by PGR with their corresponding primer sets and further confirmed by sequencing.

\section{Tissue distribution of bfNTRs mRNA}

One microgram of total RNA prepared from various tissues was reverse transcribed as described above. One microliter out of $20 \mu \mathrm{l} \mathrm{RT}$ samples was subjected to PCR. For bfNTR1 and bfNTR4, the following pairs of primers were used respectively: bfNT1-3'GSPl and bfNT1-5'GSP1; bfNT4-3'GSP1 and bfNT4-5'GSP1 (Table 1). The PGR conditions were set as follows: denaturation at $95^{\circ} \mathrm{C}$ for 3 min followed by 35 cycles at $95^{\circ} \mathrm{C}$ for $30 \mathrm{~s}, 65^{\circ} \mathrm{C}$ for $30 \mathrm{~s}, 72^{\circ} \mathrm{C}$ for $30 \mathrm{~s}$. As an internal control, bullfrog GAPDH-specific primers, GAPDH-F (5'-CAATCGAATGGGGAGCTTCTG-3') and GAPDH-R (5'-CAATCGAATGGGGAGCTT CTG-3'), were used. The PCR products and $100 \mathrm{bp}$ DNA size marker (Elpis Biotech, Daejeon, Korea) were analyzed on a $1.5 \%$ agarose gel containing ethidium bromide $(0 \cdot 5 \mu \mathrm{g} / \mathrm{ml})$.

\section{Cell culture, transfection and luciferase assay}

CV1 cells were maintained as described (Oh et al. 2003, Seong et al. 2003). CHO-K1 cells were maintained at $37^{\circ} \mathrm{C}$ in DMEM/F-12 medium with $10 \%$ heat- inactivated fetal bovine serum (FBS), $100 \mathrm{U}$ penicillin and $100 \mu \mathrm{g} / \mathrm{ml}$ streptomycin. Cells were seeded in 24-well plates and transfection was performed using the SuperFect transfection kit (Qiagen). For each transfection, $100 \mathrm{ng}$ construct cDNA and $200 \mathrm{ng}$ c-fos-luc (or CRE-luc) along with $200 \mathrm{ng}$ of the internal control plasmid pCMV $\beta$-gal were used. The empty vector pcDNA3 was used to adjust the total amount of transfected DNA. Cells were incubated in serum-free DMEM for $18 \mathrm{~h}$ before treatment with NT, NT analogs and/or NT antagonists (Table 2). Six hours after drug treatment, cells were harvested and the luciferase activity in the cell extract was determined as previously described (Oh et al. 2003). The luciferase activities were normalized using the $\beta$-galactosidase values. Transfection experiments were performed in triplicate and repeated three to five times.

\section{Establishment of stable cell lines expressing bfNTRs}

The pcDNA3 containing the ORF of bfNTR1 or bfNTR4 was transfected into CHO-K1 cells using the SuperFect transfection kit. After $24 \mathrm{~h}$, cells were treated with $400 \mu \mathrm{g} / \mu \mathrm{l}$ G418 (Clontech) for approximately 2 weeks. The large healthy colonies were selected and expanded. The presence of the stably expressing genes was confirmed by RT-PCR and CRE-luc reporter assay. CHO-K1 cells stably expressing bfNTR1 or bfNTR4 were stored in liquid nitrogen until use.

\section{IP assay}

Forty-eight hours before assay, CHO-K1 cells stably expressing bfNTR1 or bfNTR4 were seeded into 12-well plates $\left(1 \times 10^{5}\right.$ cells/well). The next day, the cells were labeled for $16-24 \mathrm{~h}$ in $1 \mathrm{ml}$ inositol-free special medium (Life Technologies, Rockville, MD, USA) containing 
$1 \mu \mathrm{Ci}$ myo $\left[{ }^{3} \mathrm{H}\right]$ inositol (Amersham Pharmacia Biotech) per well. Cells were incubated in $0.45 \mathrm{ml}$ buffer $(140 \mathrm{mM}$ $\mathrm{NaCl}, 20 \mathrm{mM}$ Hepes, $4 \mathrm{mM} \mathrm{KCl}, 8 \mathrm{mM}$ D-Glucose, $1 \mathrm{mM} \mathrm{MgCl}_{2}, 1 \mathrm{mM} \mathrm{CaCl} 2,1 \mathrm{mg} / \mathrm{ml}$ fatty acid free BSA, pH 7.2) containing $20 \mathrm{mM} \mathrm{LiCl}$ at $37^{\circ} \mathrm{C}$ for $25 \mathrm{~min}$. Then, NT was added and incubated at $37^{\circ} \mathrm{C}$ for $25 \mathrm{~min}$. The reaction was terminated by replacing the solution with $0.5 \mathrm{ml}$ ice-cold formic acid $(10 \mathrm{mM})$. IPs were extracted by incubating at $4{ }^{\circ} \mathrm{C}$ for $30 \mathrm{~min}$ and separated using a Dowex ion exchange resin. Total IPs were eluted with buffer containing $1 \mathrm{M}$ ammonium formate and $0 \cdot 1 \mathrm{M}$ formic acid. The radioactivity was counted using a liquid scintillation counter.

\section{Measurement of intracellular $\mathrm{Ca}^{2+}$ concentration $\left(\left[\mathrm{Ca}^{2+}\right]_{\mathrm{i}}\right)$}

GHO-K1 cells stably expressing bfNTR1 or bfNTR4 were grown on cover slip slides for $48 \mathrm{~h}$. The medium was removed and washed with $\mathrm{Ca}^{2+}$ buffer $(138 \mathrm{mM}$

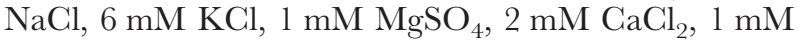
$\mathrm{Na}_{2} \mathrm{HPO}_{4}, 5 \mathrm{mM} \mathrm{NaHCO}$, $5 \mathrm{mM}$ glucose, $10 \mathrm{mM}$ Hepes, $\mathrm{pH} 7 \cdot 4,0 \cdot 1 \% \mathrm{BSA}$ ) and then incubated with buffer containing $3 \mu \mathrm{M}$ Fura-2/AM (Molecular Probes, Eugene, OR, USA) at room temperature for $1 \mathrm{~h}$. The cells were then washed and bathed in $\mathrm{Ca}^{2+}$ buffer at room temperature for at least $20 \mathrm{~min}$ before measurement of $\left[\mathrm{Ca}^{2+}\right]_{\mathrm{i}}$. The fluorescence emission of Fura-2, induced by excitation at $510 \mathrm{~nm}$, was monitored at two wavelengths ( $340 \mathrm{~nm}$ and $380 \mathrm{~nm}$ ) by a photomultiplierbased system, linked to an Olympus IX-70 microscope equipped with a $\times 40$ objective (Fluor). Three signals (340, 380 and $340 / 380 \mathrm{~nm}$ ratio) were continuously recorded with the MetaFluor Program (Downingtown, PA, USA) at $500 \mathrm{~ms}$ intervals.

\section{Radiolabeled ligand binding assay}

hNT was radioiodinated by the chloramine- $\mathrm{T}$ method and purified by chromatography on a Sephadex G-25 column as described previously (Sadoul et al. 1984). Gell membranes were prepared from $\mathrm{CHO}-\mathrm{K} 1$ cells stably expressing bfNTR1, bfNTR4 or rNTR 1 and suspended in binding buffer $\left(50 \mathrm{mM}\right.$ Tris, $2 \mathrm{mM} \mathrm{MgCl}_{2}, 1 \mathrm{mM}$ dithiothreitol, $0 \cdot 1 \% \mathrm{BSA}$ and protease inhibitor, $\mathrm{pH}$ $7 \cdot 4)$. The membrane preparation $(20 \mu \mathrm{g})$ was incubated at $16{ }^{\circ} \mathrm{C}$ for $1 \mathrm{~h}$ with increasing concentrations of ${ }^{125} \mathrm{I}$-hNT in the presence (non-specific binding) or absence (total binding) of $10 \mu \mathrm{M}$ unlabeled hNT. Specifically bound ligand was separated by rapid filtration through GF/C filters (Brandel, Gaithersburg, MD, USA) presoaked in binding buffer containing $0.01 \%$ polyethylenimine (Sigma) and washed twice with ice-cold washing buffer $\left(40 \mathrm{mM}\right.$ Tris, $2 \mathrm{mM} \mathrm{MgCl}_{2}$, $0 \cdot 1 \%$ BSA, $\mathrm{pH} 7 \cdot 4)$. Competition binding assay was carried out with intact cells in 12 -well plates at $16{ }^{\circ} \mathrm{C}$ for
$1 \mathrm{~h}$. Cells stably expressing bfNTR 1 or bfNTR 4 were incubated with 100000 c.p.m. ${ }^{125} \mathrm{I}-\mathrm{hNT}$ and increasing concentrations of unlabeled competitor in $500 \mu \mathrm{l}$ DMEM containing $0 \cdot 1 \%$ BSA. Non-specific binding was determined in the presence of $10 \mu \mathrm{M}$ unlabeled hNT.

\section{Data analysis}

All data are expressed as means \pm S.E.M. of three independent experiments. Data were analyzed using non-linear regression and plotted as sigmoid dose-response curves. Ligand concentrations inducing half-maximal stimulation $\left(\mathrm{EC}_{50}\right)$, half-maximal inhibition $\left(\mathrm{IC}_{50}\right)$ and/or maximal fold increase $\left(\mathrm{E}_{\max }\right)$ were calculated using GraphPad PRISM3.0 software (GraphPad, San Diego, CA, USA). Statistical analysis was performed by one-way ANOVA followed by a Bonferroni test. Data were considered as significant at $P<0 \cdot 05$.

\section{Results}

\section{Primary structure of bfNTRs}

Using degenerate PCR combined with $5^{\prime}$ - and 3 '-RACE, we isolated full-length cDNAs for bfNTR1 (1467 nucleotides accession No. AY613326) and bfNTR4 (1779 nucleotides accession No. AY613327). The bfNTR1 and bfNTR4 cDNAs were predicted to encode putative receptors with 422 and 400 amino acids respectively (Fig. 1). bfNTR1 and bfNTR4 exhibited the typical characteristics of GPCRs with seven hydrophobic TMHs (Fig. 1). Sequence alignment showed that bfNTR1 had a $64 \%$ amino acid identity with mammalian NTR1 and a 34-37\% identity with mammalian NTR2. bfNTR4 had a $45-47 \%$ identity with mammalian NTR2 and a $43 \%$ identity with mammalian NTR1. bfNTR 1 and bfNTR 4 showed $43 \%$ sequence identity to each other. bfNTR1 contained two potential $\mathrm{N}$-glycosylation sites in the $\mathrm{N}$-terminal domain, one potential protein kinase A (PKA) phosphorylation site in ICL1 and two potential protein kinase $\mathrm{C}(\mathrm{PKC})$ phosphorylation sites in ICL3 and the intracellular C-terminal tail (Fig. 1). While mammalian NTR2 does not possess N-glycosylation sites, bfNTR4 had two potential N-glycosylation sites in the N-terminal domain (Fig. 1). bfNTR4 contained multiple potential PKC phosphorylation sites in ICL2, ICL3 and the C-terminal tail (Fig. 1).

\section{Tissue distribution of bfNTRs mRNA}

The tissue distribution of bfNTR 1 and bfNTR 4 mRNAs was determined by RT-PCR using the primer pairs bfNT1-3'GSP1 and bfNT1-5'GSP1 (for bfNTR1) or bfNT4-3'GSP1 and bfNT4-5'GSP1 (for bfNTR4) (Table 1). The mRNA for bfNTRl was abundant in various brain regions including the olfactory lobe, 
TMH1

bENTR1 MNPGSAAEILHQPPIMRLAMTPQVPLFQEVQDFWLSTTSVMINY SNSTRHVVSEGDLDVNTDIYSKVLVTVIYLFLFVV rNTR1 MHLNSSVP---QGTPGEPDAQPFSGPQSEMEATFLALSLSNGSGNTSESDTAGPNSDLDVNTDIYSKVLVTAIYLALFVV hNTR1 MRLNSSAP----GTPGTPAADPFQRAQAGLEEALLAPGFGNASGNASERVLAAPSSELDVNTDIYSKVLVTAVYLALFVV bFNTR4 -- - - rNTR2 --hNTR2

TMH2

TMH3

bFNTR1 GCTGNSITAYTLLRKKSSMONLQSTVHYHLASLALSDLLILLLSMPIETYNFIWVHHPWAFGNVICKGYYFLRDACTYATA INTR1 GTVGNSVTAFTLARKKSLQSLQSTVHYHLGSLALSDLLILLLAMPVELYNFIWVHHPWAFGDAGCRGYYFLRDACTYATA hNTR1 GTVGNTVTAFTLARKKSLQSLQSTVHYHLGSLALSDLLTLLLAMPVELYNFIWVHHPWAFGDAGCRGYYFLRDACTYATA

rNTR2 GTTGNVLTIQLVLKKQSLHGLQGTVHYHLVSLALSDILILVISIPIELYNF IWFHYPWVFGDAVCRGYYFFRDICSYATV GTAGNALSVHVVLKARA--GRPGRLRYHVLSLALSALLLLLVSMPMELYNFVWSHYPWVFGDLGCRGYYFVRELCAYATV hNTR2 GAAGNALSVHVVLKARA--GRAGRLRHHVLSLALAGLLLLLVGVPVELYSFVWFHYPWVFGDLGCRGYYFVHELCAYATV

TMH4

$\triangle$

bENTR1

rNTR1

hNTR1

bfNTR4

rNTR2

hNTR2

LNIASLSMERYMAMCHPFKAKSIMSRSRTKKFISFIWVASLLLATPMIFAMGEIYGLGV-E---DPDHLVCTRTVEMSTF LNVASLSVERYLAICHPFKAKTLMSRSRTKKFISAIWLASALLAI PMLFTMGLQNRSGDGT---HPGGLVCTPIVDTATV LNVASLSVERYLAICHPFKAKTLMSRSRTKKFISAIWLASALLAVPMLFTMGEQNRSADGQ---HAGGLVCTPTIHTATV LNIASLSCERYLAICHPMRAKRVMSKMRTKKILAAIWVSSLIFALPMAFIMGIKYENMSPDGEPDPSSLICTSLVSTATL LSVASLSAERCLAVCQPLRARRLLTPRRTRRLLSLVWVASLGLALPMAVIMGQKHEVESADGEPEPASRVCTVLVSRATI LSVAGLSAERCLAVCQPLRARSLLTPRRTRWLVALSWAASLGLAMPMAVIMGQKHELETADGEPEPASRVCTVLVSRTAL $\stackrel{\star \star \star \star *}{\text { TMH }} \stackrel{2}{ }$

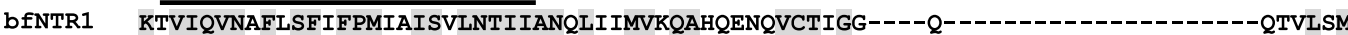

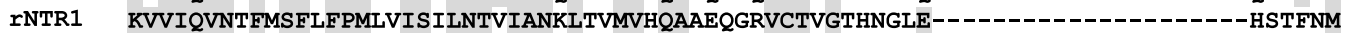

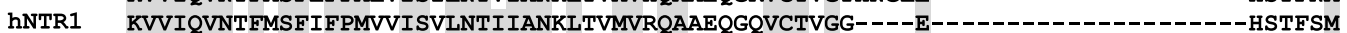
bfNTR4 KIFIQVNAFVSFVLPVTLIGGLNCITVSHLVSLRSRSSLIVHSSCKSPRASKELRKSQSSPSNLSRIPVGGTSWKKNLTV INTR2 QVFIQVNVLVSFALPLALTAFLNGITVNHLMALYSQVPSASAQVSSIP-SRLELLSEEGLLGFITWRKTLSLGVQASLVR hNTR2 QVFIQVNVLVSFVLPLALTAFLNGVTVSHLLALCSQVPSTSTPGSSTP-SRLELLSEEGLLSFIVWKKTFIQGGQVSLVR

\section{0} 77 76

TMH7

bFNTR1 SMEPSRIQSLKHGVRVLRVVVIAFVVCWLPYHVRRLMFCYVPEELWTDELNDFYHYFYMLTNVLFYVSSTVNPILYNLVS INTR1 TIEPGRVOALRHGVLVLRAVVIAFVVCWLPYHVRRLMFCYISDEOWTTFLFDFYHYFYMLTNALFYVSSAINPILYNLVS hNTR1 AIEPGRVQALRHGVRVLRAVVIAFVVCWLPYHVRRLMFCYISDEQWTPFLYDFYHYFYMVTNALFYVSSTINPILYNLVS bFNTR4 SSEPNRIQSLQHSIYMLRAIVIAYIVCWLPYHARRLMFCYIPDDDWSGSLYTFYHYFYMLTNTLFYISSAVNPVLYNVVS INTR2 HKDASQIRSLQHSAQVLRAIVAVYVICWLPYHARRLMYCYIPDDGWTNELYDFYHYFYMVTNTLFYVSSAVTPILYNAVS hNTR2 HKDVRRIRSLQRSVQVLRAIVVMYVICWLPYHARRLMYCYVPDDAWTDPLYNFYHYFYMVTNTLFYVSSAVTPLLYNAVS 362 $\star \star \star \star$

$\begin{array}{rlr}\text { bfNTR1 } & \text { ANFRQIFVSTLSFLCPPWR-RKKKHPGFSBKSNSISSTNHTFSTQITRETPY } & 422 \\ \text { rNTR1 } & \text { ANFRQVFLSTLACLCPGWRHRRKRPTFSRKPNSMSS-NHAFSTSATRETLY } & 424 \\ \text { hNTR1 } & \text { ANFRHIFLATLACLCPVWR-RRRKRPAFSRKADSVSS-NHTLSSNATRETLY } & 418 \\ \text { bFNTR4 } & \text { SSFRKLFLETLSPSCSKQNSNFSIKSSSSHIRPD } & 400 \\ \text { rNTR2 } & \text { SSFRKLFLESLGSLCGEQHSLVPLPQEAPESTTSTYSFRLWGSPRNPSLGEIQV } & 416 \\ \text { hNTR2 } & \text { SSFRRLFLEAVSSLCGEHPMKRLPPK-PQSPTLMDTASGFGDPPETRT } & 410\end{array}$

Figure 1 Sequence alignment of the bullfrog (bf), human (h) and rat ( $r$ ) NTRs. Amino acid sequences of the indicated NTRs were aligned using MacVector Software (Acce Irys, San Diego, CA, USA). The conserved amino acid residues are shaded. The numbers on the right side indicate the position of amino acid residues. The putative N-glycosylation sites, PKC and PKA phosphorylation sites are indicated by diamonds, circles and squares respectively. The predicted seven transmembrane helices (TMHs) are indicated above the aligned sequences. Asp in TMH2 and Asn in TMH7 that are highly conserved in rhodopsin-like GPCRs are indicated by dots. The two Cys residues suggested to form a disulfide bridge between ECL1 and ECL2 are indicated by solid triangles. Two conserved motifs D/ERY and NPXXY are indicated by asterisks. GenBank accession Nos are hNTR1: P30989; hNTR2: O95665; rNTR1: P20789; rNTR2: Q63384.

cerebral cortex and hypothalamus, as well as in the spinal cord (Fig. 2). The mRNA for bfNTR4 was abundant in the cerebral cortex and hypothalamus, but weakly expressed in the olfactory lobe and spinal cord (Fig. 2). In the distal and neurointermediate lobes of the pituitary, bfNTRl mRNA was highly expressed, while bfNTR4 mRNA was moderately expressed. At the periphery, weak signals for bfNTR 1 were detected in the heart, kidney and small intestine. An intense signal for bfNTR4 was observed in the ovary (Fig. 2).

\section{Differential signal transduction for mammalian and bullfrog NTRs}

To investigate the signaling pathways of bfNTRs, CV-1 cells or CHO-K1 cells were co-transfected with either bfNTR1, bfNTR4, rNTR1 or hNTR2 in combination with the c-fos-luc (or CRE-luc) reporter vector. We have previously shown that c-fos-luc and CRE-luc reporter are sensitive to phospholipase $\mathrm{C}$ (PLG)/PKG- and adenylate cyclase (AC)/PKA-linked signaling pathways 


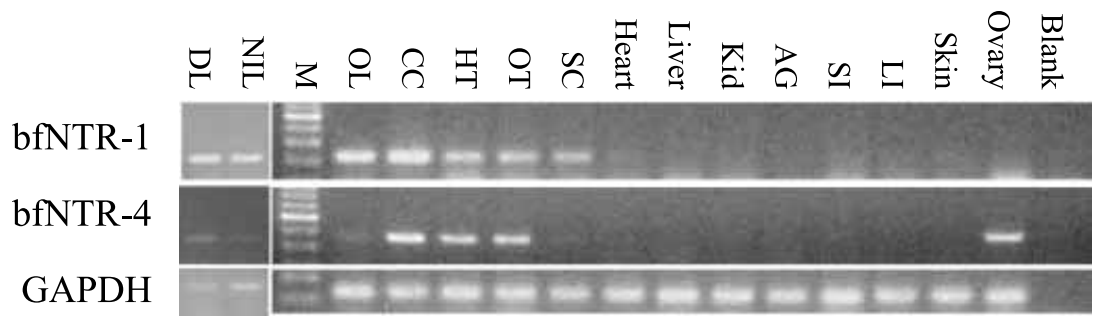

Figure 2 RT-PCR analysis of bullfrog (bf) NTRs in a variety of tissues. Total RNAs isolated from the distal lobe (DL) and neurointermediate lobe (NIL) of the pituitary, olfactory lobe (OL), cerebral cortex (CC), hypothalamus (HT), optic tectum (OT), spinal cord (SC), heart, liver, kidney (Kid), adrenal gland (AG), small intestine (SI), large intestine (LI), skin and ovary were subjected to RT-PCR.

respectively (Oh et al. 2003, Seong et al. 2003). Activation of bfNTR1 by hNT strongly increased both c-fos-luc and CRE-luc reporter activity with similar strength. bfNTR4 slightly induced c-fos-luc and CRE-luc activity when expressed in CV1 cells. When expressed in CHO-K1 cells, bfNTR4 was able to induce a 9-fold increase in CRE-luc activity but only a 4-fold increase in c-fos-luc activity (Fig. 3). rNTR1 induced both CRE-luc and c-fos-luc reporter activity in $\mathrm{CVl}$ and $\mathrm{CHO}-\mathrm{K} 1$ cells. In contrast, no significant increase in CRE-luc and c-fos-luc reporter activity was observed in either CV1 or CHO-K1 cells expressing hNTR2 (Fig. 3) or mNTR2 (data not shown).

NT-induced IP production and $\left[\mathrm{Ca}^{2+}\right]_{\mathrm{i}}$ elevation were determined in $\mathrm{CHO}-\mathrm{K} 1$ cells stably expressing bfNTR1 or bfNTR4. In agreement with the c-fos-luc assay results, hNT induced a 3-fold increase in IP production in cells expressing bfNTR 1 and only a $1 \cdot 5$-fold increase in cells expressing bfNTR4 (Fig. 4). Exposure of CHO-K1 cells expressing bfNTR1 or bfNTR 4 to hNT provoked an immediate elevation of $\left[\mathrm{Ca}^{2+}\right]_{\mathrm{i}}$ and the $\mathrm{Ca}^{2+}$ signal lasted for at least $45 \mathrm{~s}$ (Fig. 5A and B). In mock-transfected cells, hNT did not induce $\left[\mathrm{Ca}^{2+}\right]_{\mathrm{i}}$ increase although thapsigargin, an inhibitor of sarcoendoplasmic $\mathrm{Ca}^{2+}$ ATPase, was able to increase $\left[\mathrm{Ca}^{2+}\right]_{\mathrm{i}}$, indicating that Fura-2 was successfully loaded (Fig. 5C).

\section{Effect of peptide agonists on NTRs}

Ligand selectivity was examined using the c-fos-luc and CRE-luc reporter systems. In the c-fos-luc assay system, bfNTR 1 and rNTR 1 exhibited similar patterns of ligand

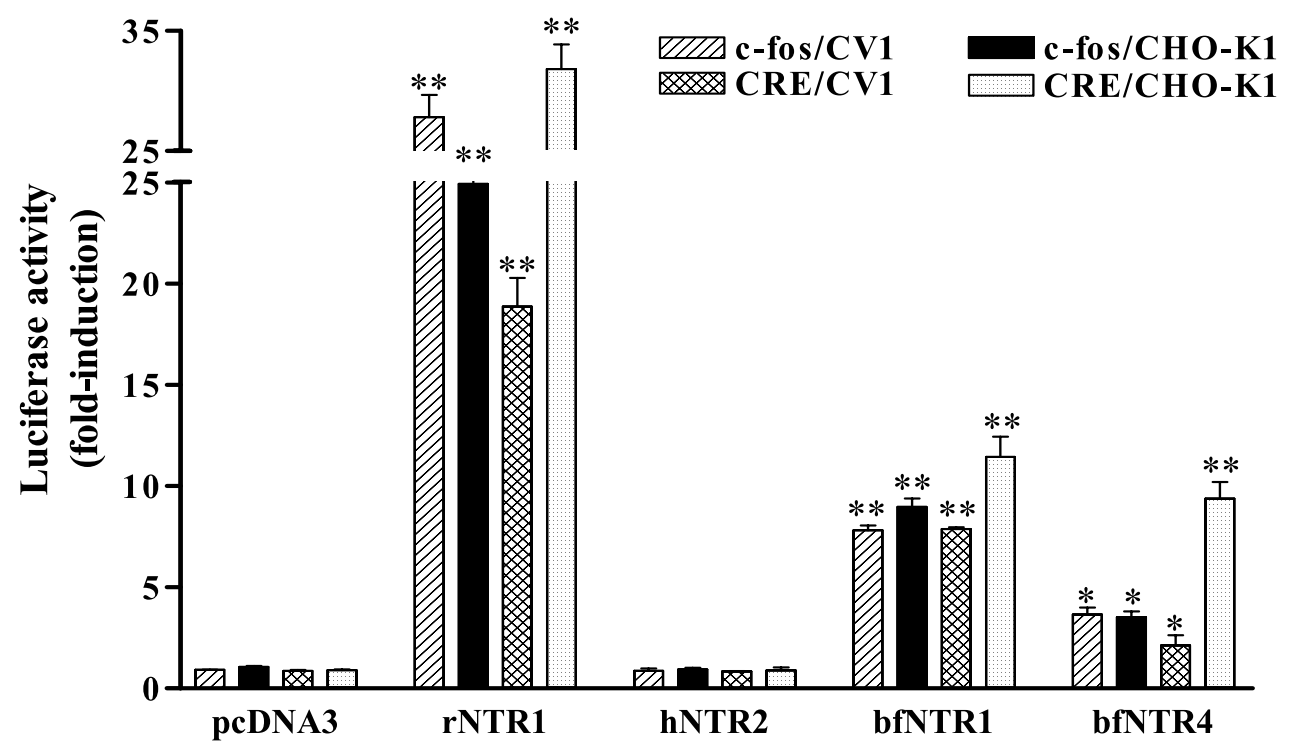

Figure 3 hNT-induced CRE-luc and c-fos-luc reporter activity. CV1 or CHO-K1 cells were transfected with $200 \mathrm{ng}$ CMV $\beta$-gal and $200 \mathrm{ng}$ c-fos-luc or CRE-luc plus $100 \mathrm{ng}$ individual pcDNA3, rat (r) NTR1, human (h) NTR2, bullfrog (bf) NTR1 or bfNTR4. One day after transfection, cells were serum-starved for $24 \mathrm{~h}$ followed by $6 \mathrm{~h}$ treatment with $1 \mu \mathrm{M} \mathrm{hNT}$. Results shown are the mean of duplicate observations from a single representative experiment. ( $\left.{ }^{\star} P<0.05 ;{ }^{\star \star} P<0.01\right)$. 


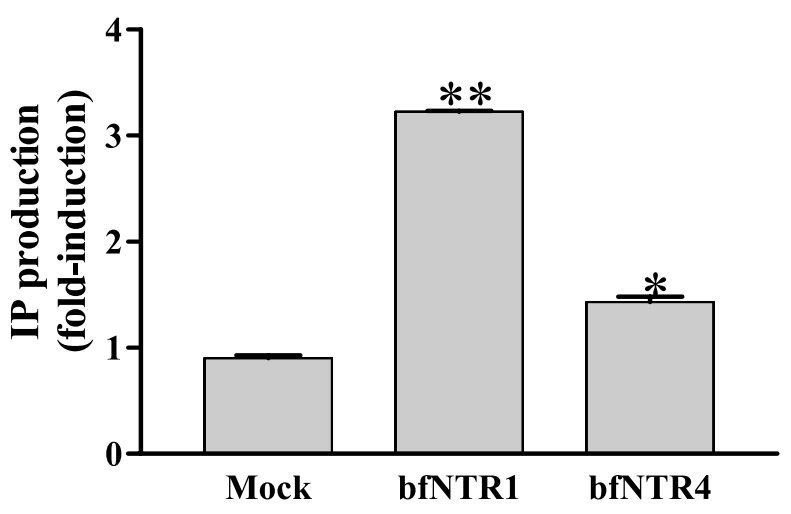

Figure 4 IP accumulation in cells expressing bullfrog (bf) NTRs. CHO-K1 cells stably expressing each bfNTR or mock-transfected cells were seeded in 12-well plates $\left(1 \times 10^{5}\right.$ per well). One day after seeding, cells were grown in inositol-free DMEM containing $1 \mu \mathrm{Ci} m y o-\left[{ }^{3} \mathrm{H}\right]$ inositol/well and $2 \%$ FBS for $24 \mathrm{~h}$ and then treated with $1 \mu \mathrm{M}$ hNT for $6 \mathrm{~h}$. IP production was expressed as fold-induction over basal. Data shown are the means \pm S.E.M. of three independent experiments. $\left({ }^{\star} P<0.01,{ }^{\star \star} P<0.001\right)$.

sensitivity toward NTs and different pseudopeptide analogs. fNT showed the highest potency for both bfNTR1 and rNTR1, followed by $\mathrm{hNT} \approx \mathrm{JMV}$ $458 \approx \mathrm{NT}(8-13)>\mathrm{pNMN}>\mathrm{JMV} \quad 510 \approx \mathrm{JMV} \quad 457 \approx \mathrm{JMV}$ 431 (Fig. 6 and Table 3). Compared with rNTR1 and bfNTR1, bfNTR4 showed slightly lower sensitivity to these compounds (Fig. 6 and Table 3). In the CRE-luc assay system, rNTR1 and bfNTR1 exhibited a similar pattern of ligand sensitivity as observed in the c-fos-luc assay system. It is of interest to note that bfNTR4 showed a slightly higher sensitivity to all NT analogs, except pNMN, than bfNTRl (Fig. 7 and Table 3).

\section{Effect of non-peptide ligands on NTRs}

SR 48692 and SR 142948A are known to function as antagonists for mammalian NTR1 and agonists for mammalian NTR2 (Botto et al. 1997, Gully et al. 1997, Vita et al. 1998). Indeed, SR 142948 A and SR 48692 showed antagonistic activity to rNTR1, the former having a higher potency than the latter (Fig. 8A and Table 4). SR 142948A completely inhibited hNTinduced CRE-luc activity in bfNTR1-expressing cells, while SR 48692 marginally inhibited hNT-induced CRE-luc activity in these cells (Fig. 8B and Table 4). Both SR 142948A and SR 48692 showed an antagonistic property for bfNTR4 (Fig. 8C). In particular, SR $142948 \mathrm{~A}$ was a potent antagonist $\left(\mathrm{IC}_{50}=\right.$ $-9 \cdot 1 \pm 0 \cdot 2$ ) for bfNTR4. Levocabastine, at high concentrations, induced CRE-luc activity in cells expressing bfNTR1 and bfNTR4, but not in rNTR1transfected cells (Fig. 8D and Table 4).

\section{Binding affinity of bfNTR1 and bfNTR4}

The binding properties of bfNTR1 and bfNTR4 were examined using ${ }^{125} \mathrm{I}-\mathrm{hNT}$ as a radioligand. Specific binding to membranes prepared from CHO-Kl cells expressing bfNTR1, bfNTR4 or rNTR1 was observed while only background binding occurred in mocktransfected CHO-K1 cells. Saturation experiments revealed that hNT had a high affinity to each NTR (Fig. 9A and B): $K_{\mathrm{d}}=0 \cdot 88 \pm 0 \cdot 12 \mathrm{nM}$ for bfNTR1, $1.29 \pm 0.23 \mathrm{nM}$ for bfNTR4 and $0.83 \pm 0.14 \mathrm{nM}$ for rNTR1). Maximum binding $\left(B_{\max }\right)$ was as follows: $7 \cdot 61 \pm 0 \cdot 49, \quad 12 \cdot 24 \pm 1 \cdot 15$ and $10 \cdot 6 \pm 0 \cdot 84 \mathrm{pmol} / \mathrm{mg}$ protein for bfNTR1, bfNTR4 and rNTR1 respectively.

Displacement experiments showed that hNT could efficiently inhibit the binding of ${ }^{125} \mathrm{I}$-hNT to bfNTRl and to bfNTR4, indicating hNT has a high affinity for both receptors. In bfNTR1-expressing cells, SR 142948A showed a 100-times lower affinity than hNT, while in bfNTR4-expressing cells, SR 142948A had similar affinity to hNT. Levocabastine exhibited very low affinity for both bfNTR4 and bfNTR1 (Fig. 9C and $\mathrm{D}$ and Table 4).
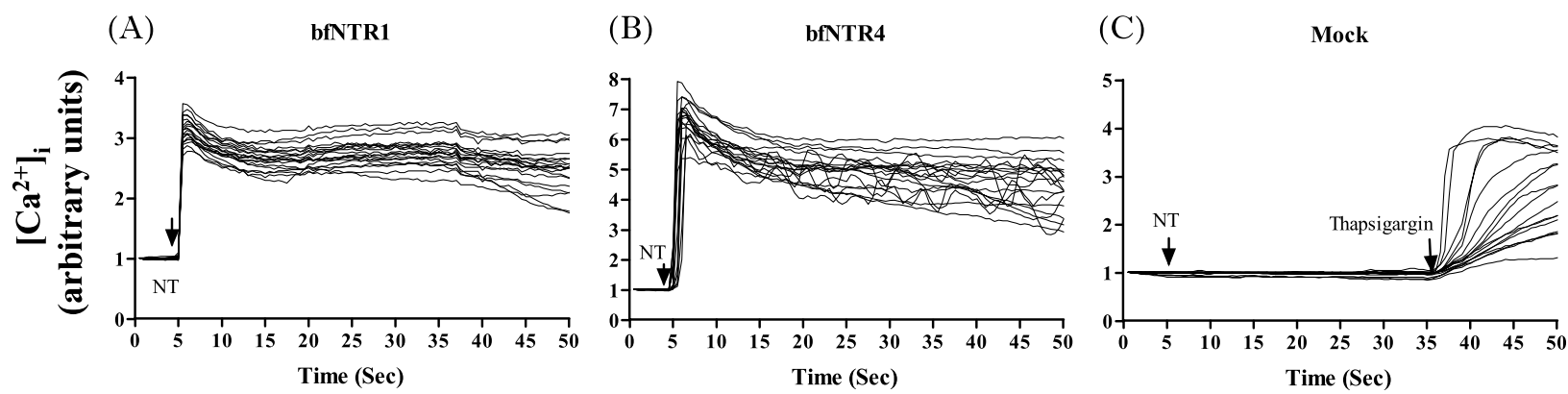

Figure 5 Effect of NT on intracellular $\mathrm{Ca}^{2+}$ concentration $\left(\left[\mathrm{Ca}^{2+}\right]_{\mathrm{i}}\right)$ in $\mathrm{CHO}-\mathrm{K} 1$ cells expressing bullfrog (bf) NTRs. CHO-K1 cells stably expressing bfNTR1 (A) or bfNTR4 (B) and mock-transfected cells (C) were challenged with $1 \mu \mathrm{M}$ hT. Data show the means \pm S.E.M. of $\sim 15$ individual recordings of $\left[\mathrm{Ca}^{2+}\right]_{\mathrm{i}}$ during $100 \mathrm{~s}$. Cells were exposed to thapsigargin (1 mM) to confirm Fura-2 loading $(\mathrm{C})$. 


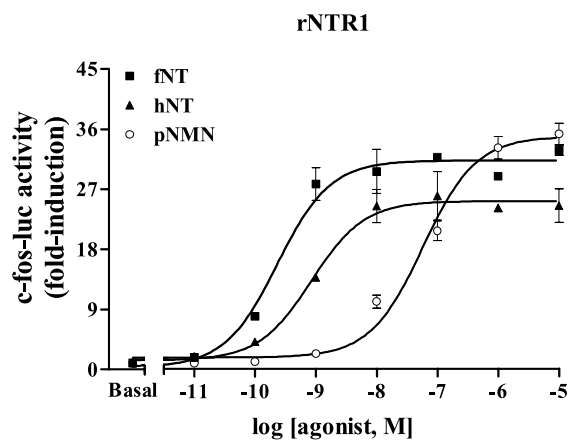

rNTR1

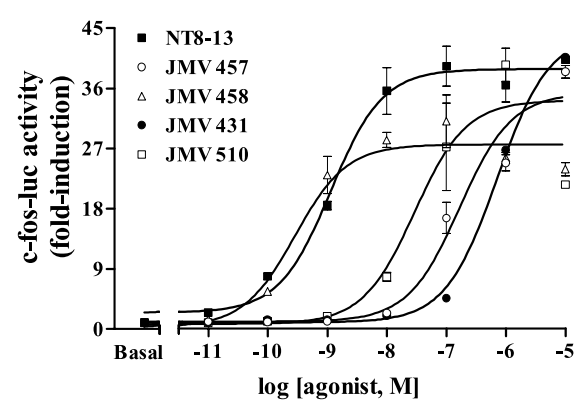

bfNTR1

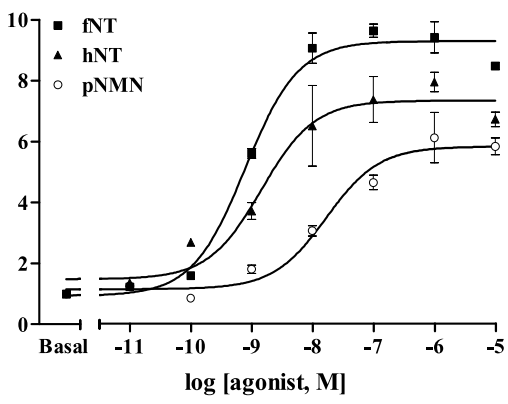

bfNTR1

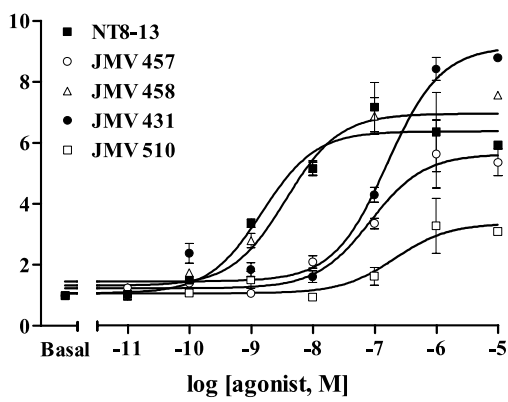

bfNTR4

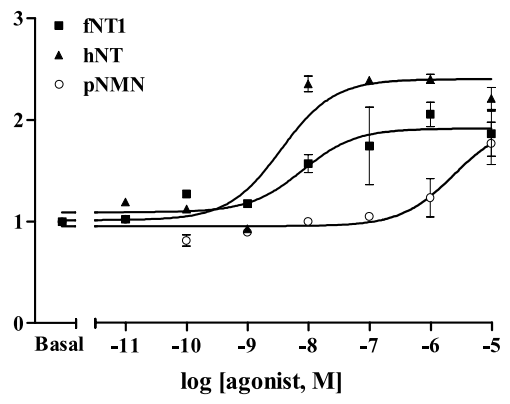

bfNTR4

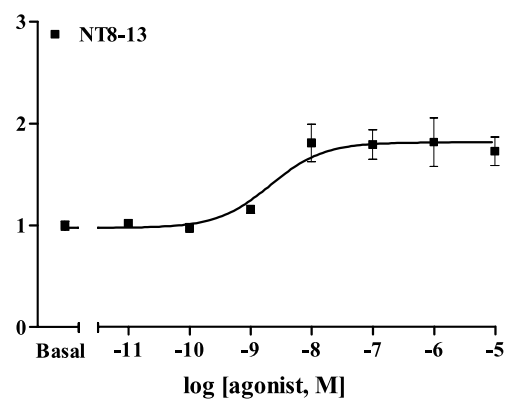

Figure 6 Differential ligand selectivity of rat ( $r$ ) NTR1, bullfrog (bf) NTR1 and bfNTR4. CV1 cells were transfected with 200 ng CMV $\beta$-gal and $200 \mathrm{ng}$ c-fos-luc plus $100 \mathrm{ng}$ rNTR1, bfNTR1 or bfNTR4. One day after transfection, cells were serum-starved for another $24 \mathrm{~h}$, then treated for $6 \mathrm{~h}$ with graded concentrations of various agonists and luciferase activity was measured. Data are means \pm S.E.M. of one representative experiment from three to five experiments.

Table 3 Ligand selectivity of NTRs. Cells were transfected with NTR in combination with c-fos-luc reporter (CV1 cells) or CRE-luc reporter (CHO-K1 cells). $\mathrm{EC}_{50}$ (log $\mathrm{M}$ ) and $\mathrm{E}_{\max }$ (fold-increase over basal) values are obtained from c-fos-luc or CRE-luc reporter assay systems. Each value indicates the mean \pm S.E.M. from three independent experiments

rNTR1

$\mathrm{EC}_{50}$

c-fos-luc activity (CV1 cells)

fNT

hNT

pNMN

NT8-13

JMV457

JMV458

JMV431

JMV510

\section{CRE-luc activity (CHO-K1 cells)}

fNT

hNT

pNMN

NT8-13

JMV457

JMV458

Levocabastine
$-9 \cdot 6 \pm 0 \cdot 1$

$-9 \cdot 1 \pm 0 \cdot 1$

$-7 \cdot 2 \pm 0 \cdot 1$

$-8 \cdot 9 \pm 0.1$

$-6 \cdot 8 \pm 0 \cdot 1$

$-9 \cdot 5 \pm 0.2$

$-6 \cdot 2 \pm 0 \cdot 0$

$-7.5 \pm 0.3$

\section{$-8 \cdot 8 \pm 0 \cdot 2$}

$-9 \cdot 0 \pm 0 \cdot 2$

$-7 \cdot 3 \pm 0 \cdot 1$

$-8 \cdot 3 \pm 0 \cdot 1$

$-6 \cdot 5 \pm 0 \cdot 2$

$-9 \cdot 0 \pm 0 \cdot 1$

ND

\section{bfNTR1}

\begin{tabular}{|c|c|}
\hline $\mathrm{EC}_{50}$ & $\mathrm{E}_{\max }$ \\
\hline $\begin{array}{l}-9 \cdot 1 \pm 0 \cdot 1 \\
-8 \cdot 8 \pm 0 \cdot 2 \\
-7 \cdot 8 \pm 0 \cdot 2 \\
-8 \cdot 8 \pm 0 \cdot 1 \\
-7 \cdot 1 \pm 0 \cdot 2 \\
-8 \cdot 4 \pm 0 \cdot 2 \\
-6 \cdot 8 \pm 0 \cdot 1 \\
-6 \cdot 7 \pm 0 \cdot 4\end{array}$ & $\begin{array}{l}9 \cdot 3 \pm 0.2 \\
7 \cdot 4 \pm 0.3 \\
5 \cdot 9 \pm 0.2 \\
6 \cdot 4 \pm 0 \cdot 2 \\
5 \cdot 6 \pm 0.3 \\
7 \cdot 0 \pm 0.3 \\
9 \cdot 2 \pm 0.4 \\
3 \cdot 4 \pm 0.4\end{array}$ \\
\hline
\end{tabular}

$53 \cdot 7 \pm 2 \cdot 3$

$55 \cdot 7 \pm 2 \cdot 2$

$29 \cdot 2 \pm 1 \cdot 2$

$33 \cdot 2 \pm 1 \cdot 3$

$23 \cdot 2 \pm 1 \cdot 7$

$8 \cdot 3 \pm 0 \cdot 3$

ND
bfNTR4

\begin{tabular}{|c|c|}
\hline $\mathrm{EC}_{50}$ & $\mathrm{E}_{\max }$ \\
\hline $\begin{array}{c}-8 \cdot 0 \pm 0 \cdot 4 \\
-8 \cdot 5 \pm 0 \cdot 2 \\
-5 \cdot 6 \pm 0 \cdot 3 \\
-8 \cdot 7 \pm 0 \cdot 3 \\
\text { ND } \\
\text { ND } \\
\text { ND } \\
\text { ND }\end{array}$ & $\begin{array}{c}1 \cdot 9 \pm 0 \cdot 1 \\
2 \cdot 4 \pm 0 \cdot 1 \\
2 \cdot 0 \pm 0 \cdot 2 \\
1 \cdot 8 \pm 0 \cdot 1 \\
\text { ND } \\
\text { ND } \\
\text { ND } \\
\text { ND }\end{array}$ \\
\hline $\begin{array}{l}-9 \cdot 1 \pm 0 \cdot 2 \\
-9 \cdot 3 \pm 0 \cdot 1 \\
-6 \cdot 0 \pm 0 \cdot 1 \\
-8 \cdot 8 \pm 0 \cdot 3 \\
-6 \cdot 4 \pm 0 \cdot 1 \\
-9 \cdot 0 \pm 0 \cdot 2 \\
-5 \cdot 2 \pm 0.5\end{array}$ & $\begin{array}{r}6.7 \pm 0.3 \\
7.4 \pm 0.2 \\
10.0 \pm 0.6 \\
8.4 \pm 0.5 \\
7.3 \pm 0.4 \\
6.4 \pm 0.3 \\
4.1 \pm 1 \cdot 2\end{array}$ \\
\hline
\end{tabular}

$\mathrm{ND}$, not detected. 
rNTR1

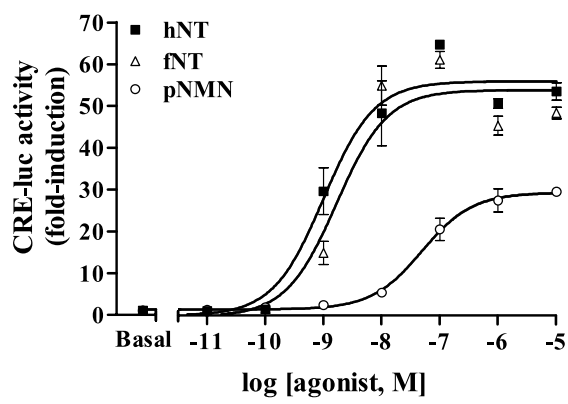

rNTR1

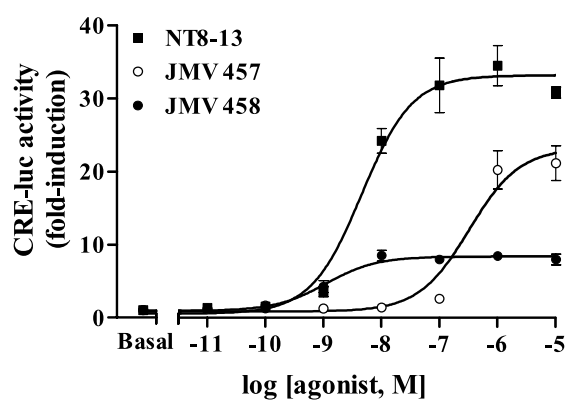

bfNTR1
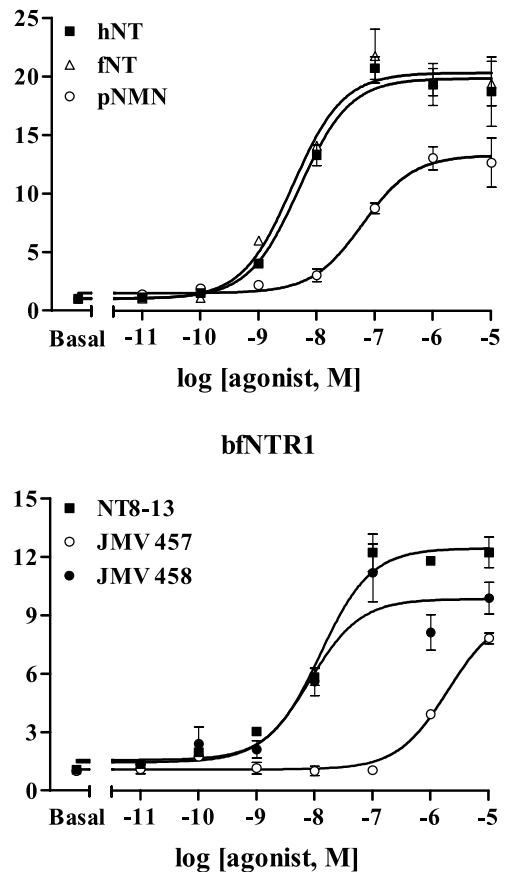

bfNTR4

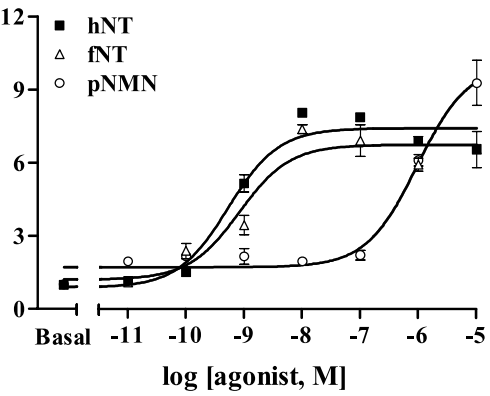

bfNTR4

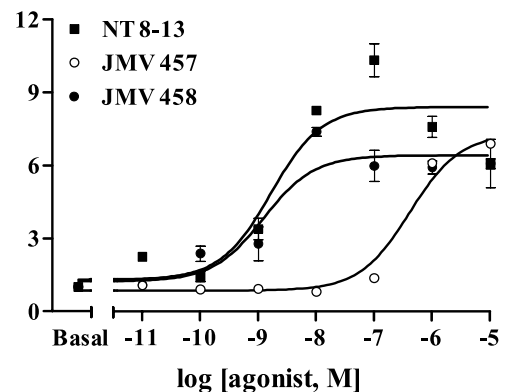

Figure 7 Differential ligand selectivity of rat ( $r$ ) NTR1, bullfrog (bf) NTR1 and bfNTR4. CHO-K1 cells were transfected with 200 ng CMV $\beta$-gal and $200 \mathrm{ng}$ CRE-luc plus $100 \mathrm{ng}$ rNTR1, bfNTR1 or bfNTR4. One day after transfection, cells were serum-starved for another $24 \mathrm{~h}$, then treated for $6 \mathrm{~h}$ with graded concentrations of various agonists, and luciferase activity was measured. Data are means \pm S.E.M. of one representative experiment from three to five experiments.

\section{Discussion}

This report has described for the first time the identification and functional characterization of two non-mammalian NTRs. As previously described for mammalian NTRs, bfNTR1 and bfNTR4 were mainly expressed in the brain and pituitary. bfNTR1 has a high degree of sequence identity with mammalian NTR1 while bfNTR4 exhibits a relatively low similarity to either mammalian NTR1 or NTR2. They differed in signal transduction pathways and ligand affinity from each other. Further, they exhibited distinct pharmacological characteristics from those of the mammalian receptors.

bfNTR 1 exhibited a high degree of sequence identity and structural similarity with the corresponding mammalian receptor NTR1. Like mammalian NTR1, bfNTR1 has a long extracellular N-terminal domain and a short extracellular loop 3 (ECL3). A Thr-X-Tyr motif in the $\mathrm{C}$-terminal domain, which is critical for internalization of mammalian NTR1 (Chabry et al. 1995), was also found in bfNTR1. bfNTR 4 has a short extracellular N-terminal domain and a relatively long ECL3, characteristics of mammalian NTR2. bfNTR4, however, showed some structural differences with mammalian NTR2. First, mammalian NTR2 does not contain glycosylation sites in the extracellular N-terminal domain while bfNTR4 possesses two putative glycosylation sites in the $\mathrm{N}$-terminal region as found in mammalian NTR1. Secondly, the sequence of ICL1 in bfNTR4 is different from that of mammalian NTR2 but similar to that of mammalian NTR1 and bfNTR1. As the ICLs are involved in G protein coupling and signal transduction, it could be anticipated that differences in the signaling pathways occur between mammalian NTR2 and bfNTR4. Thirdly, the two conserved residues $\mathrm{Asp}^{2 \cdot 50} / \mathrm{Asn}^{7 \cdot 49}$ in $\mathrm{TMH} 2 / \mathrm{TMH} 7$, which are characteristic of the rhodopsin-like GPCR family, are absent in the mammalian NTR2 but present in bfNTR4. The presence of $\mathrm{Asp}^{2 \cdot 50} / \mathrm{Asn}^{7 \cdot 49}$ residues is important for receptor conformation as they are involved in a hydrogen bond interaction responsible for the close association of TMH2 and TMH7 (Sealfon et al. 1997). It has been reported that the conserved Asp ${ }^{2 \cdot 50}$ residue in TMH2 accounts for the $\mathrm{Na}^{+}$sensitivity and/or receptor activation in rNTRl as in other GPCRs (Kong et al. 1993, Martin et al. 1999, Belmeguenai et al. 2000). Indeed, the mutation on these residues critically affects receptor activation (Awara et al. 1996). Further, the $\mathrm{Asn}^{7 \cdot 49}$ residue followed by the Pro-X-X-Tyr motif is known to be involved in coupling with the small G protein ARF and RhoA (Mitchell et al. 
(A)

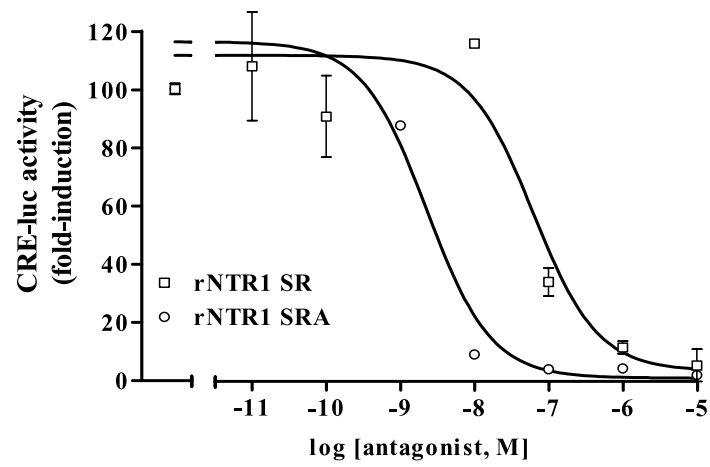

(C)

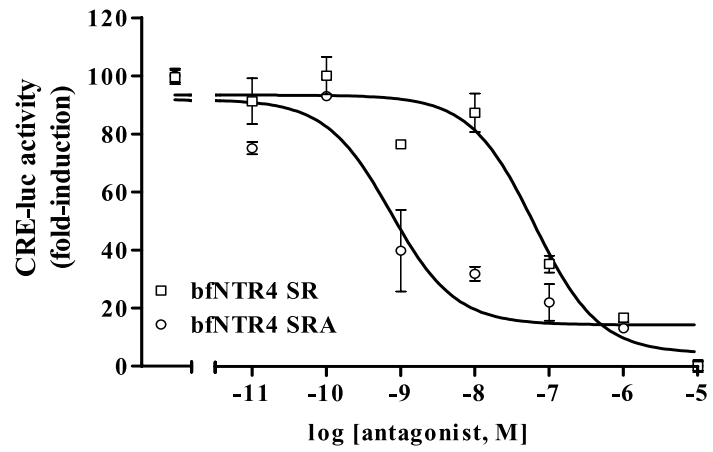

(B)

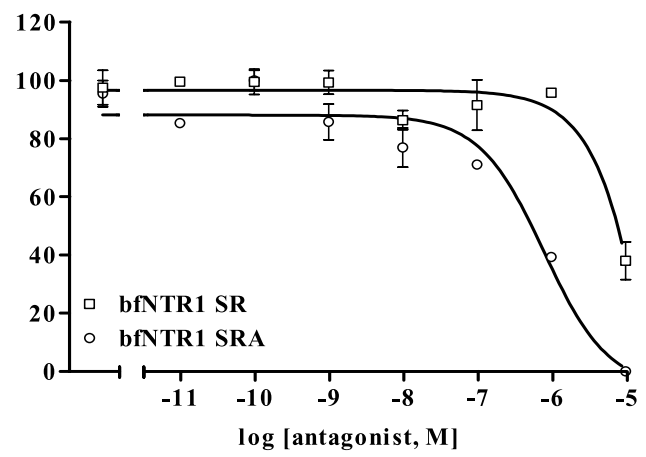

(D)

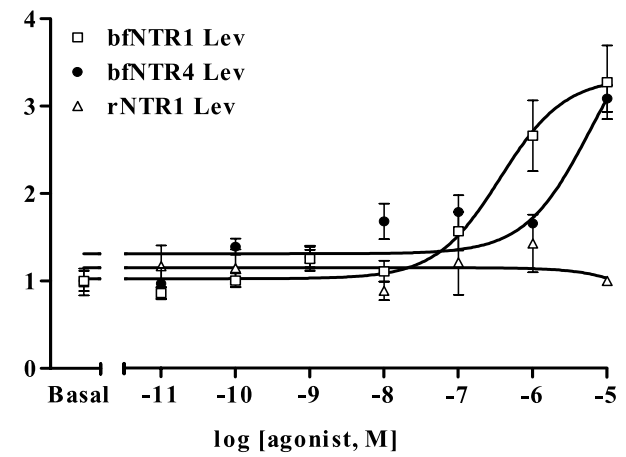

Figure 8 Effects of antagonists on rat (r) NTR1, bullfrog (bf) NTR1 and bfNTR4. CHO-K1 cells were transfected with $200 \mathrm{ng} \mathrm{CMV} \beta$-gal and $200 \mathrm{ng}$ CRE-luc plus $100 \mathrm{ng}$ rNTR1 (A), bfNTR1 (B) or bfNTR4 (C). One day after transfection, cells were serum-starved for another $24 \mathrm{~h}$, then treated for $6 \mathrm{~h}$ with graded concentrations of SR 48692 (SR) or SR 142948A (SRA) in the presence of $1 \mathrm{nM} \mathrm{hNT}$. (D) Effect of graded concentrations of levocabastine on bfNTR1-, bfNTR4- and NTR1-expressing cells. Data are means \pm S.E.M. of one representative experiment from three to five experiments

1998). Thus, the presence of the $\mathrm{Asp}^{2 \cdot 50} / \mathrm{Asn}^{7 \cdot 49}$ residues in bfNTR4 may be responsible for differential signal transduction coupling and ligand sensitivity, as com-

Table $4 \mathrm{IC}_{50}$ of SR 48692, SR 142948A and levocabastine to various NTRs. For the CRE-luc assay, $\mathrm{CHO}-\mathrm{K} 1$ cells transiently expressing NTRs together with CRE-luc reporter were used. For the binding asay, CHO-K1 cells stably expressing NTRs were used. $I_{50}(\log M)$ more values obtained from the CRE-luc assay and competition binding assay respectively. Values are the mean \pm S.E.M. from three independent experiments

\begin{tabular}{|c|c|c|c|}
\hline \multirow{2}{*}{ CRE-Iuc assay } & \multicolumn{3}{|c|}{$\mathbf{I C}_{50}(\log \mathrm{M})$} \\
\hline & rNTR1 & bfNTR1 & bfNTR4 \\
\hline $\begin{array}{l}\text { CRE-luc assay } \\
\text { SR } 48692 \\
\text { SR } 142948 \text { A }\end{array}$ & $\begin{array}{l}-7 \cdot 2 \pm 0 \cdot 2 \\
-8 \cdot 6 \pm 0 \cdot 1\end{array}$ & $\begin{array}{c}\mathrm{PI} \\
-6 \cdot 1 \pm 0 \cdot 2\end{array}$ & $\begin{array}{l}-7 \cdot 2 \pm 0.2 \\
-9 \cdot 1 \pm 0.2\end{array}$ \\
\hline $\begin{array}{l}\text { Binding assay } \\
\text { NT } \\
\text { Sr 142948A } \\
\text { Levocabastine }\end{array}$ & $\frac{-}{-}$ & $\begin{array}{c}-9 \cdot 1 \pm 0 \cdot 1 \\
-6 \cdot 6 \pm 0 \cdot 1 \\
\text { ND }\end{array}$ & $\begin{array}{l}-9 \cdot 2 \pm 0 \cdot 2 \\
-8 \cdot 8 \pm 0 \cdot 2 \\
-5 \cdot 8 \pm 0 \cdot 3\end{array}$ \\
\hline
\end{tabular}

$\mathrm{PI}$, partial inhibition; ND, not determined. pared with mammalian NTR2. However, we do not exclude the possibility that bfNTR4 and mammalian NTR2 originate from the same ancestral gene as they show a global similarity in structure to some extent.

Consistent with a previous report showing that mNTR2 stably expressed in HEK293 cells is able to bind radioiodinated NT but cannot induce any signaling cascade, including PLC and AC activation (Botto et al. 1998), we found that NT did not induce CRE-luc and c-fos-luc reporter activity in $\mathrm{GV1}$ or $\mathrm{CHO}-\mathrm{K} 1$ cells expressing hNTR2 or mNTR2. Thus, although mammalian NTR2 can bind NT and NT agonists, its ability to induce signal transduction is very low. Unlike mammalian NTR2, bfNTR4 was able to induce CRE-luc and c-fos-luc reporter activities as well as IP production and elevation of $\left[\mathrm{Ca}^{2+}\right]_{\mathrm{i}}$. The fact that bfNTR 4 has a better signaling activity than mammalian NTR2 is consistent with the structural differences described above. bfNTR4 could induce both CRE-luc and c-fos-luc reporter activity but their fold-increases depended on the cell line in which the receptor was transfected. Thus, in GVl cells, bfNTR4 induced a 
(A)

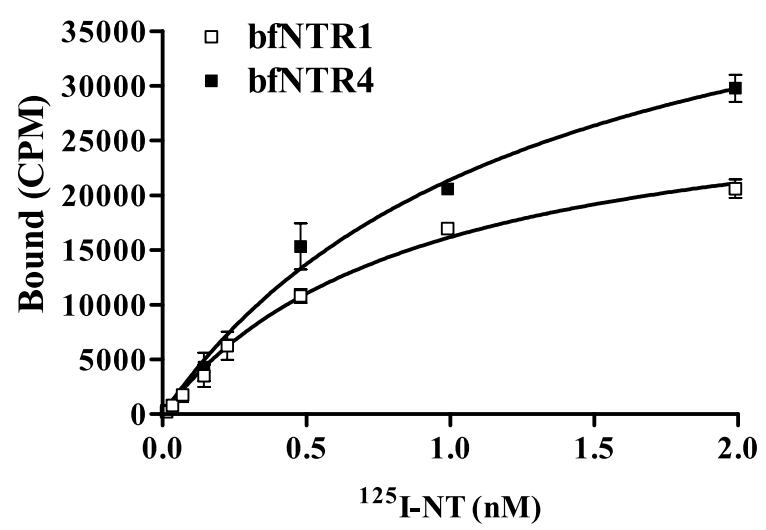

(C)

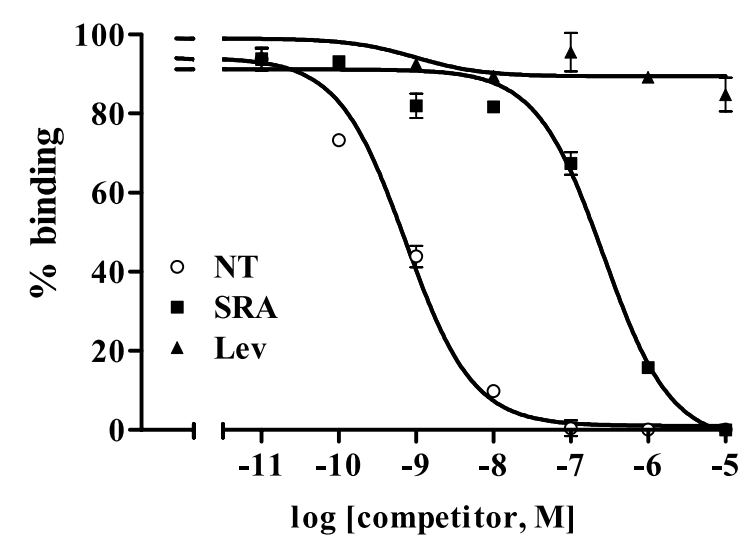

(B)

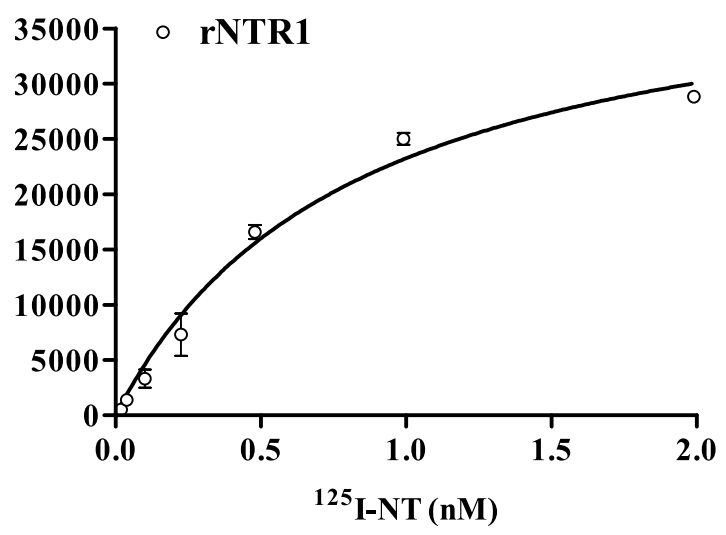

(D) bfNTR4

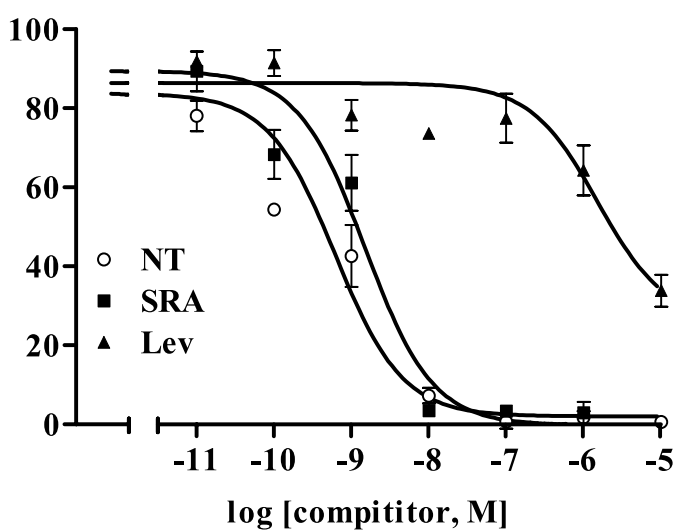

Figure 9 Binding assays. CHO-K1 cells stably expressing bullfrog (bf) NTR1, bfNTR4 (A) and rat (r) NTR1 (B) were applied to a saturation-binding assay using graded concentrations of ${ }^{125} \mathrm{I}-\mathrm{hNT}$. Non-specific binding was determined in the presence of $10 \mu \mathrm{M}$ unlabeled hNT. Competitive inhibition of ${ }^{125}$ I-hNT binding on cells expressing bfNTR1 (C) or bfNTR4 (D) by cold NT (circles), SR 142948A (squares), or levocabastine (triangles). The results are expressed as the percent specific binding. Data are means \pm S.E.M. of one representative experiment from three to five experiments.

similar fold increase in CRE-luc and c-fos-luc reporter activity, while in CHO-K1 cells bfNTR4 produced a $2 \cdot 0$-fold higher increase in CRE-luc activity (9-fold) than in c-fos-luc activity (4-fold). Since bfNTR1 provoked a similar induction of c-fos-luc and CRE-luc reporter activity, it appears that bfNTR l may trigger both the AC/PKA- and PLC/PKC-linked signaling pathways with similar strength, at least in CHO-K1 cells, while bfNTR4 may activate preferentially the AC/PKA-linked signaling pathway. Consistent with this observation, bfNTR4-expressing CHO-K1 cells exhibited only a 1.5-fold increase in IP production, while bfNTR1expressing CHO-K1 cells showed approximately a 3 -fold increase in IP production. However, results obtained from these cellular tools cannot simply be extrapolated to a normal physiological situation, which is very complicated as tissues contain the target receptor but also its isoforms as well as a variety of splice variants. Further, the coupling efficiency to the effectors is largely dependent on the cellular context ( $\mathrm{Oh}$ et al. 2003).

There is now clear evidence that NT is an important neuroendocrine regulator of the hypothalamo-pituitary system (McCann \& Vijayan 1992, Rostène \& Alexander 1997). In particular, in the frog, fNT stimulates the electrical and secretory activity of melanotrope cells through an activation of a receptor whose pharmacological profile shares similarities with mammalian NTR1 (Labbé-Jullié et al. 1994, Desrues et al. 1998, Belmeguenai et al. 2000). In this model, the most potent agonist is JMV 458 followed by JMV 457, JMV 510 and JMV 431 (Belmeguenai et al. 2000). The specific NTR1 antagonist SR 48692 does not inhibit fNTevoked stimulation of melanotrope cells, while the 
wide-spectrum antagonist SR 142948A completely blocks the response (Belmeguenai et al. 2000). Consistent with this observation, the present study showed that JMV 458 exhibited the highest potency to stimulate bfNTR1 followed by JMV 457, JMV 510 and JMV 431 and that SR 142948A but not SR 48692 completely blocked bfNTR1 activation induced by NT. These pharmacological data strongly suggest that fNT-induced stimulation of frog melanotrope cells is mediated through the NTR1 receptor subtype. In support of this hypothesis, we found that, in the bullfrog neurointermediate lobe, bfNTR $1 \mathrm{mRNA}$ was actively expressed whereas bfNTR4 was hardly detectable.

Strong evolutionary pressure has acted to conserve the structure of the C-terminal hexapeptide of NT(8-13) from amphibians to mammals (Table 2) and this region is known to bear the biological activity of the peptide (Rostène \& Alexander 1997). In accord, NT(8-13) was found to have the same potency as hNT and fNT in inducing activation of bfNTR1 and bfNTR4. The low potency of pNMN, JMV 457, JMV 510 and JMV 431 might be ascribed to replacement of the $\mathrm{Arg}^{9}$ by an Ile or Lys residue and/or by substitution for a bulky amino acid at position 11, which are known to affect ligand binding (Pang et al. 1996). It is noteworthy that, in the c-fos-luc assay system, bfNTR1 showed a higher sensitivity than bfNTR4 to all agonists used in the present study whereas, in the CRE-luc reporter assay system, bfNTR4 responded better to these agonists, except for $\mathrm{pNMN}$, than did bfNTR1. The reason for the differential sensitivity toward each signaling pathway is currently unknown. It may be due to differential coupling efficiency of the receptors or differential receptor trafficking (Kenakin 2001).

One serendipitous finding of this study is that bfNTRs exhibited distinct pharmacological properties as compared with mammalian NTRs. SR 142948A completely inhibited NT-induced rNTR1 activation with a higher potency than SR 48692, which is in good agreement with a previous report (Gully et al. 1997). SR 48692 and SR 142948A, however, showed a relatively low potency to inhibit the activity of bfNTR1, the bullfrog counterpart of mammalian NTR1. Surprisingly, SR 48692 and SR 142948A, which act as agonists on mammalian NTR2 (Botto et al. 1997), strongly inhibited NT-induced bfNTR4 activity. The residues $\mathrm{Met}^{208}$ in TMH4, $\mathrm{Tyr}^{324}$, $\mathrm{Arg}^{327}$ and $\mathrm{Phe}^{331}$ in TMH6 and $\mathrm{Tyr}^{351}$, Thr ${ }^{354}$, Phe ${ }^{358}, \mathrm{Tyr}^{359}$ in TMH7 of rNTR1 play a crucial role in SR 48692 binding (Labbé-Jullié et al. 1998). As these residues are conserved in bfNTR 1 and bfNTR4, it is assumed that other nearby residues are involved in the differential selectivity of bfNTR 1 and bfNTR4 for SR 142948A and SR 48692. Levocabastine, an agonist for mammalian NTR2 but not for NTR1, induced CRE-luc reporter activity in both bfNTR1- and bfNTR4-expressing cells. Altogether, these data indicate that, despite the high sequence similarity among bfNTRs and mammalian NTRs, bfNTRs have different characteristics compared with mammalian NTRs in terms of ligand selectivity and signal transduction. As the agonists and antagonists for mammalian NTRs exhibit different functionalities on the amphibian NTRs, one should be careful when using these NT analogs to characterize NTRs in non-mammalian vertebrates.

The characterization of two fNTRs provides novel information regarding the phylogenetic history of G protein-coupled NTRs in the vertebrate lineage. The fact that bfNTR4 exhibits structural and functional similarities to mammalian NTR1 suggests that the ancestral gene from which the two receptors arose encoded an NTR1-like receptor. Duplication of the ancestral NTR gene, which probably occurred before the divergence of the amphibian and mammalian lineages, gave rise to two distinct genes that may have evolved at vastly different rates. Thus, while bfNTR 1 closely resembles its rat and human counterparts, the structural and functional characteristics of amphibian NTR4 and mammalian NTRs are more divergent. Further, while bfNTR4 has clearly retained NT as a natural agonist, mNTR2 and hNTR2 are insensitive to NT, suggesting that, in the mammalian phylum, NTR2 may have adopted a novel, yet unknown, peptide ligand. Finally, comparison of the sequences of amphibian and mammalian receptors will provide important clues as to the structural determinants that are responsible for ligand selectivity and signal transduction coupling.

In conclusion, this report provides the first molecular, pharmacological and functional characterization of two NTRs in a non-mammalian vertebrate. The data show that bfNTRs exhibit differential ligand selectivity and signal coupling mechanisms from each other, as well as distinct functional characteristics as compared with their mammalian counterparts. These data should help to elucidate the evolutionary history of NTRs in the vertebrate lineage and to identify the structural motifs that determine their pharmacological and physiological properties.

\section{Acknowledgements}

We thank Dr J Mazella (CNRS, Valbonne, France) for the gift of mammalian NTRs, Dr J Martinez (CNRS, Montpellier, France) for the gift of NT analogs, Dr M C Lagrange and G Le Fur (Sanofi-Synthelabo) for the gift of SR 48692 and SR 142948A and Dr M Janssen (Janssen Pharmaceutica, Beerse, Belgium) for the gift of levocabastine. This work was supported by a grant (M103 KV010004 03K2201 00410) to J Y S from the Brain Research Center of the 21 st Century Frontier Research Program, a grant (R01-2004-000-10163-0) 
to H B K from the Ministry of Sciences and Technology, INSERM (U413) and a STAR exchange program to JYS and $\mathrm{H} \mathrm{V}$. The authors declare that there is no conflict of interest that would prejudice the impartiality of this scientific work.

\section{References}

Awara WM, Guo CH \& Conn PM 1996 Effects of Asn ${ }^{318}$ and $\mathrm{Asp}^{87} \mathrm{Asn}^{318}$ mutations on signal transduction by the gonadotropin-releasing hormone receptor and receptor regulation. Endocrinology 137 655-662.

Bello AR, Kah O, Tramu G \& Conlon JM 1993 Purification and primary structure of alligator neurotensin. Peptides 14 1055-1058.

Belmeguenai A, Vaudry H, Leprince J, Vivet B, Cavelier F,

Martinez J \& Louiset E 2000 Neurotensin modulates the electrical activity of frog pituitary melanotropes via activation of a G-protein-coupled receptor pharmacologically related to both the NTS1 and NTS2 receptors of mammals. Neuroendocrinology 72 379-391.

Betancur C, Canton M, Burgos A, Labeeuw B, Gully D, Rostene W \& Pelaprat D 1998 Characterization of binding sites of a new neurotensin receptor antagonist, $\left[{ }^{3} \mathrm{H}\right] \mathrm{SR} 142948 \mathrm{~A}$, in the rat brain. European fournal of Pharmacology 343 67-77.

Botto JM, Guillemare E, Vincent JP \& Mazella J 1997 Effects of SR 48692 on neurotensin-induced calcium-activated chloride currents in the Xenopus oocyte expression system: agonist-like activity on the levocabastine-sensitive neurotensin receptor and absence of antagonist effect on the levocabastine insensitive neurotensin receptor. Neuroscience Letters 223 193-196.

Botto JM, Chabry J, Sarret P, Vincent JP \& Mazella J 1998 Stable expression of the mouse levocabastine-sensitive neurotensin receptor in HEK 293 cell line: binding properties, photoaffinity labeling, and internalization mechanism. Biochemical and Biophysical Research Communications 243 585-590.

Carraway RE \& Bhatnagar YM 1980 Isolation, structure and biological activity of chicken intestinal neurotensin. Peptides $\mathbf{1}$ 167-174.

Carraway RE \& Leeman SE 1973 The isolation of a new hypotensive peptide, neurotensin, from bovine hypothalami. Fournal of Biological Chemistry 248 6854-6861.

Carraway RE \& Mitra SP 1998 Neurotensin enhances agonist-induced cAMP accumulation in PC3 cells via $\mathrm{Ca}^{2+}$-dependent adenylyl cyclase(s). Molecular and Cellular Endocrinology 144 47-57.

Chabry J, Labbé-Jullié C, Gully D, Kitabgi P, Vincent JP \& Mazella J 1994 Stable expression of the cloned rat brain neurotensin receptor into fibroblasts: binding properties, photoaffinity labeling, transduction mechanisms, and internalization. Fournal of Neurochemistry 63 19-27.

Chabry J, Botto JM, Nouel D, Beaudet A, Vincent JP \& Mazella J 1995 Thr-422 and Tyr-424 residues in the carboxyl terminus are critical for the internalization of the rat neurotensin receptor. Fournal of Biological Chemistry 270 2439-2442.

Chalon P, Vita N, Kaghad M, Guillemot M, Bonnin J, Delpech B, Le Fur G, Ferrara P \& Caput D 1996 Molecular cloning of a levocabastine-sensitive neurotensin binding site. FEBS Letters $\mathbf{3 8 6}$ 91-94.

Conlon JM, Adrian TE \& Secor SM 1997 Tachykinins (substance P, neurokinin A and neuropeptide $\gamma$ and neurotensin from the intestine of the Burmese python, Python molurus. Peptides $\mathbf{1 8}$ $1505-1510$.

Dal Farra C, Sarret P, Navarro V, Botto JM, Mazella J \& Vincent JP 2001 Involvement of the neurotensin receptor subtype NTR3 in the growth effect of neurotensin on cancer cell lines. International Fournal of Cancer 92 503-509.

Desrues L, Tonon MC, Leprince J, Vaudry H \& Conlon JM 1998 Isolation, primary structure, and effects on $\alpha$-melanocyte-stimulating hormone release of frog neurotensin. Endocrinology $1394140-4146$.

Dubuc I, Sarret P, Labbe-Jullie C, Botto JM, Honore E, Bourdel E, Martinez J, Costentin J, Vincent JP, Kitabgi P et al. 1999 Identification of the receptor subtype involved in the analgesic effect of neurotensin. Fournal of Neuroscience 19 503-510.

Gailly P, Najimi M \& Hermans E 2000 Evidence for the dual coupling of the rat neurotensin receptor with pertussis toxin-sensitive and insensitive G-proteins. FEBS Letters 483 109-113.

Gully D, Canton M, Boigegrain R, Jeanjean F, Molimard JC, Poncelet M, Gueudet C, Heaulme M, Leyris R, Brouard A et al. 1993 Biochemical and pharmacological profile of a potent and selective nonpeptide antagonist of the neurotensin receptor. PNAS 90 65-69.

Gully D, Labeeuw B, Boigegrain R, Oury-Donat F, Bachy A, Poncelet M, Steinberg R, Suaud-Chagny MF, Santucci V, Vita N et al. 1997 Bio-chemical and pharmacological activities of SR 142948 A, a new potent neurotensin receptor antagonist. Fournal of Pharmacology and Experimental Therapeutics 280 802-812.

Hermans E, Gailly P, Octave JN \& Maloteaux JM 1994 Rapid desensitization of agonist-induced calcium mobilization in transfected PC12 cells expressing the rat neurotensin receptor. Biochemical and Biophysical Research Communications 198 400-407.

Kenakin T 2001 Inverse, protean, and ligand-selective agonism: matters of receptor conformation. FASEB Fournal 15 598-611.

Kitabgi P 2002 Targeting neurotensin receptors with agonists and antagonists for therapeutic purposes. Current Opinions in Drug Discovery and Development 5 764-776.

Kitabgi P, Carraway R \& Leeman SE 1976 Isolation of a tridecapeptide from bovine intestinal tissue and its partial characterization as neurotensin. Fournal of Biological Chemistry 251 7053-7058.

Kong H, Raynor K, Yasuda K, Bell GI \& Reisine T 1993 Mutation of an aspartate at residue 89 in somatostatin receptor subtype 2 prevents $\mathrm{Na}^{+}$regulation of agonist binding but does not alter receptor-G protein association. Molecular Pharmacology 44 380-384.

Labbé-Jullié C, Dubuc I, Brouard A, Doulut S, Bourdel E, Pélaprat D, Mazella J, Martinez J, Rostène W, Costentin J et al. 1994 In vivo and in vitro structure-activity studies with peptide and pseudopeptide neurotensin analogs suggest the existence of distinct central neurotensin receptor subtypes. Fournal of Pharmacology and Experimental Therapeutics 268 328-336.

Labbé-Jullié C, Barroso S, Nicolas-Eteve D, Reversat JL, Botto JM, Mazella J, Bernassau JM \& Kitabgi P 1998 Mutagenesis and modeling of the neurotensin receptor NTR1. Identification of residues that are critical for binding SR 48692, a nonpeptide neurotensin antagonist. Fournal of Biological Chemistry $\mathbf{2 7 3}$ 16351-16357.

Maeno H, Yamada K, Santo-Yamada Y, Aoki K, Sun YJ, Sato E, Fukushima T, Ogura H, Araki T, Kamichi S et al. 2004 Comparison of mice deficient in the high- or low-affinity neurotensin receptors, Ntsr1 or Ntst2, reveals a novel function for Ntsr2 in thermal nociception. Brain Research 998 122-129.

Martin S, Botto JM, Vincent JP \& Mazella J 1999 Pivotal role of an aspartate residue in sodium sensitivity and coupling to $\mathrm{G}$ proteins of neurotensin receptors. Molecular Pharmacology 55 210-215.

Martin S, Vincent JP \& Mazella J 2003 Involvement of the neurotensin receptor-3 in the neurotensin-induced migration of human microglia. Fournal of Neuroscience 23 1198-1205.

Mazella J, Botto JM, Guillemare E, Coppola T, Sarret P \& Vincent JP 1996 Structure, functional expression, and cerebral localization of the levocabastine-sensitive neurotensin/neuromedin $\mathrm{N}$ receptor from mouse brain. Fournal of Neuroscience 16 5613-5620. 
Mazella J, Zsurger N, Navarro V, Chabry J, Kaghad M, Caput D, Ferrara P, Vita N, Gully D, Maffrand JP et al. 1998 The 100-kDa neurotensin receptor is gp95/sortilin, a non-G-protein-coupled receptor. Foumal of Biological Chemistry 273 26273-26276.

McCann SM \& Vijayan E 1992 Control of anterior pituitary hormone secretion by neurotensin. Annals of the New York Academy of Sciences 668 287-297.

McMahon BM, Boules M, Warrington L \& Richelson E 2002 Neurotensin analogs: indications for use as potential antipsychotic compounds. Life Sciences 70 1101-1119.

Mitchell R, McCulloch D, Lutz E, Johnson M, MacKenzie C, Fennell M, Fink G, Zhou W \& Sealfon SC 1998 Rhodopsinfamily receptors associate with small $\mathrm{G}$ proteins to activate phospholipase D. Nature 392 411-414.

Nykjaer A, Lee R, Teng KK, Jansen P, Madsen P, Nielsen MS, Jacobsen C, Kliemannel M, Schwarz E, Willnow TE et al. 2004 Sortilin is essential for proNGF-induced neuronal cell death. Nature 427 843-848.

Oh DY, Wang L, Ahn RS, Park JY, Seong JY \& Kwon HB 2003 Differential $G$ protein coupling preference of mammalian and nonmammalian gonadotropin-releasing hormone receptors. Molecular and Cellular Endocrinology 205 89-98.

Pang YP, Cusack B, Groshan K \& Richelson E 1996 Proposed ligand binding site of the transmembrane receptor for neurotensin(8-13). Fournal of Biological Chemistry 271 $15060-15068$.

Remaury A, Vita N, Gendreau S, Jung M, Arnone M, Poncelet M, Culouscou JM, Le Fur G, Soubrie P, Caput D et al. 2002 Targeted inactivation of the neurotensin type 1 receptor reveals its role in body temperature control and feeding behavior but not in analgesia. Brain Research 953 63-72.

Richard F, Barroso S, Martinez J, Labbe-Jullie C \& Kitabgi P 2001 Agonism, inverse agonism, and neutral antagonism at the constitutively active human neurotensin receptor 2. Molecular Pharmacology 60 1392-1398.

Rostène WH \& Alexander MJ 1997 Neurotensin and neuroendocrine regulation. Frontiers in Neuroendocrinology 18 $115-173$.

Sadoul JL, Mazella J, Amar S, Kitabgi P \& Vincent JP 1984 Preparation of neurotensin selectively iodinated on the tyrosine 3 residue. Biological activity and binding properties on mammalian neurotensin receptors. Biochemical and Biophysical Research Communications 120 812-819.

Sarret P, Gendron L, Kilian P, Nguyen HM, Gallo-Payet N, Payet MD \& Beaudet A 2002 Pharmacology and functional properties of NTS2 neurotensin receptors in cerebellar granule cells. Fournal of Biological Chemistry 277 36233-36243.

Sealfon SC, Weinstein H \& Millar RP 1997 Molecular mechanisms of ligand interaction with the gonadotropin-releasing hormone receptor. Endocrine Reviews 18 180-205.
Seong JY, Wang L, Oh DY, Yun O, Maiti K, Li JH, Soh JM, Choi HS, Kim K, Vaudry H et al. $2003 \mathrm{Ala} / \mathrm{Thr}(201)$ in extracellular loop 2 and leu/phe(290) in transmembrane domain 6 of type 1 frog gonadotropin-releasing hormone receptor confer differential ligand sensitivity and signal transduction. Endocrinology 144 $454-466$.

Shaw C, McKay DM, Halton DW, Thim L \& Buchanan KD 1992 Isolation and primary structure of an amphibian neurotensin. Regulatory Peptides 38 23-31.

Sicard F, Vaudry H, Braun B, Chartrel N, Leprince J, Conlon JM \& Delarue C 2000 Immunohistochemical localization, biochemical characterization, and biological activity of neurotensin in the frog adrenal gland. Endocrinology 141 2450-2457.

Somai S, Gompel A, Rostene W \& Forgez P 2002 Neurotensin counteracts apoptosis in breast cancer cells. Biochemical and Biophysical Research Communications 295 482-488.

Tanaka K, Masu M \& Nakanishi S 1990 Structure and functional expression of the cloned rat neurotensin receptor. Neuron $\mathbf{4}$ 847-854.

Vincent JP, Mazella J \& Kitabgi P 1999 Neurotensin and neurotensin receptors. Trends in Pharmacological Sciences 20 302-309.

Vita N, Laurent P, Lefort S, Chalon P, Dumont X, Kaghad M, Gully D, Lefur G, Ferrara P \& Caput D 1993 Cloning and expression of a complementary DNA encoding a high affinity human neurotensin receptor. FEBS Letters 317 139-142.

Vita N, Oury-Donat F, Chalon P, Guillemot M, Kaghad M, Bachy A, Thurneyssen O, Garcia S, Poinot-Chazel C, Casellas P et al. 1998 Neurotensin is an antagonist of the human neurotensin NT2 receptor expressed in Chinese hamster ovary cells. European fournal of Pharmacology 360 265-272.

Watson MA, Yamada M, Yamada M, Cusack B, Veverka K, Bolden-Watson C \& Richelson E 1992 The rat neurotensin receptor expressed in Chinese hamster ovary cells mediates the release of inositol phosphates. Fournal of Neurochemistry $\mathbf{5 9}$ 1967-1970.

Yamada M, Yamada M, Watson MA \& Richelson E 1993 Neurotensin stimulates cyclic AMP formation in CHO-rNTR-10 cells expressing the cloned rat neurotensin receptor. European Fournal of Pharmacology 244 99-101.

Yamada M, Yamada M, Lombet A, Forgez P \& Rostene W 1998 Distinct functional characteristics of levocabastine sensitive rat neurotensin $\mathrm{NT}_{2}$ receptor expressed in Chinese hamster ovary cells. Life Sciences 62 375-380.

Yamauchi R, Usui H, Yunden J, Takenaka Y, Tani F \& Yoshikawa M 2003 Characterization of $\beta$-lactotensin, a bioactive peptide derived from bovine $\beta$-lactoglobulin, as a neurotensin agonist. Bioscience, Biotechnology, and Biochemistry 67 940-943.

Received 28 January 2005

Accepted 1 February 2005

Made available online as an Accepted Preprint 2 February 2005 